\title{
Formy życia w grach schematami - i na odwrót
}

\author{
Hans Lenk \\ http://orcid.org/0000-0003-2910-3671
}

$\mathrm{W}$ artykule zostaje zarysowana koncepcja reprezentowanego przez autora metodologicznego interpretacjonizmu schematycznego; zostaje ona powiązana z Wittgensteinowską filozofią gier językowych i form życia: gry schematami poszerzają i fundują koncepcję gry językowej, mogą też - za pośrednictwem form życia i światów życia - głębiej ugruntować intepretacje wzgl. perspektywicznie dać im owocne wyjaśnienie.

Słowa kluczowe: Wittgenstein, gry językowe, formy życia, świat życia, gry schematami

\section{Schematy w poznaniu i działaniu}

Człowiek poznaje i działa tylko wtedy, gdy schematyzuje i strukturyzuje. Postrzega jedynie za pośrednictwem bądź też $w$ strukturach, myśli $w$ i poprzez sche-

Oryginał tekstu w języku niemieckim był publikowany w „Kulturze i Wartościach” w roku 2014, w numerze 12, s. 45-62; http://kulturaiwartosci.umcs.lublin.pl/numery-archiwalne/numer-412-2014/; http://journals.umcs.pl/kw/article/view/640. Przypisy i bibliografia zostały w przekładzie dostosowane do stylu Chicago [The Chicago Manual of Style (Notes and Bibliography)]. W przypisach i bibliografii, o ile to możliwe, podane zostały polskie wydania cytowanych tekstów [przyp. red.].

HANS LENK, profesor emerytowany, Instytut Technologii w Karlsruhe, Niemcy; e-mail: hans.lenk@kit.edu 
maty, działa w ramach względnie uporządkowanej formy czy to celów, norm, rutyn, czy to impulsów popędowych. W ogóle trzeba mocno podkreślić, że człowiek jest wprawdzie również, ale nie tylko istotą poznającą. Nie może całkowicie wycofać się do sfery czystego ducha, gdyż rozwój i aktywizacja „ducha” są zawsze uwikłane w sytuacje określone przez działanie - a zatem w każdorazowe światy przeżywania wzgl. „formy życia” (również w znaczeniu, jakie temu pojęciu nadał Wittgenstein), tak że poznanie i działanie pozostają w pewnym sensie nierozerwalnie powiązane ${ }^{2}$. Człowiek, który działa i poznaje, musi również być w stanie postrzegać, odbierać i przetwarzać zewnętrzne wpływy i wrażenia - a to wszystko odbywa się za pośrednictwem ustrukturyzowanych wzorów. By wykorzystać zdolność do ich reprezentowania, tj. do rozpoznawania relacji między reprezentującym słowem lub znakiem wzgl. symbolem a intendowanym przedmiotem, człowiek musi w istocie dysponować umiejętnością dokonywania zasadniczej wykładni, interpretacji, a także zdolnością do działania. By przedstawiać, świadomie postrzegać, a zatem reprezentować, człowiek musi uzmienniać swoje przedstawienia, musi być elastyczny duchowo, rozwijać alternatywy, musi umieć percypować, musi konstytuować, konstruować w szerokim tego słowa znaczeniu. Człowiek musi również mieć zdolność konstruowania reprezentacji na poziomach wyższych („metapoziomach”), w ścisłym znaczeniu tego słowa. Ujmując rzecz zwięźle: człowiek musi schematyzować oraz interpretować schematy.

To, co nazywam filozofią interpretacjonizmu schematów jest perspektywą, do której skłoniła mnie metodologiczna analiza przeprowadzana w ramach teorii wiedzy, rozwijana przeze mnie od czterech dziesięcioleci. Przy tym wracam do Kantowskiej tradycji strukturyzowania naszych doświadczeń i wszelkich „ujęć” (jak lubię to nazywać) za pośrednictwem z góry danych lub dopiero kształtowanych „form” (schematów). Z drugiej strony, wychodzę również od przykładów i pojęć z zakresu teorii wiedzy nauk społecznych, zwłaszcza psychologii.

Każde poznanie jest konstrukcją, powiadają psychologowie. Również poznanie dokonane przez myślenie wyższego stopnia jest w tym właśnie sensie konstruktywne, wymodelowane, ujęte we wzory, ustrukturyzowane przez schematy, zatem zależne od schematów bądź też ukształtowane lub zaimpregnowane przez

\footnotetext{
${ }^{2}$ Przy czym „działanie” rozumiem tu nawet w szerszym znaczeniu - łącznie ze zdolnością do reaktywnego zachowania, a zatem nie tylko jako działanie przebiegające świadomie i planowo.
} 
schematy: konstrukcja i zastosowanie schematów mogą w ogólności oznaczać tworzenie i stosowanie „konstruktów interpretacyjnych”, wytwarzanie ,interpretantów schematów” lub „konstruktów interpretacji schematów”. Dotyczy to zarówno przyporządkowania, jak i pierwszego strukturyzowania i porządkowania. Rzecz jasna, ważne jest przy tym zarówno aktualizowanie i aktywizowanie, jak i reaktywowanie schematu na podstawie określonych sygnałów bodźcowych w percepcji zarówno wizualnej, jak i akustycznej bądź taktylnej. Schematyzacja zachodzi jednak również na płaszczyźnie abstrakcyjnej, na wyższych metastopniach języków lub teorii. Człowiek musi umieć reprezentować i interpretować na metapoziomie.

Trzeba też podkreślić, że schemat użyty do szczególnej sytuacji poznawczej lub sytuacji strukturyzowania - co rzecz jasna dotyczy zarówno działania, jak i przedstawiającego strukturyzowania - musi być schematem, który należy poddać instancjalizacji. Instancjalizacja schematu oznacza, że schemat jest nastawiony na pojedynczy przypadek o określonych wartościach początkowych i brzegowych, początkowych danych i określonych wartościach granicznych; musi on więc być skonkretyzowany, aby ustrukturyzowaną liczbę cech sytuacyjnych umieścić, ująć i odnieść do ogólniejszych, wyuczonych, zapamiętanych i wciąż od nowa aktualizowanych schematów w określonych ramach - powiedzmy w obrębie jakiejś „formy życia”.

Można powiedzieć, że całość schematów jest niejako systemem hipotetycznym, quasi prywatnym i osobistym odzwierciedleniem „przeżytego" wycinka rzeczywistości wzgl. „formy życia” - nie tylko, ale również w znaczeniu Wittgensteinowskim $^{4}$ - odpowiednio ustrukturyzowanego względem zewnętrznych lub „zewnętrznych" rzeczywistości. Ta całość obejmuje takie struktury, które dana osoba - lub poznający podmiot - wytworzyła bądź rozwinęła w konfrontacji ze środowiskiem, w tej mierze, w jakiej struktury te nie są ustalone dziedzicznie (jak na przykład schematy odruchowe).

Psycholodzy mówią o „naiwnych teoriach” codzienności, których każdy używa w celu porządkowania, wyjaśniania i opisu wszystkich fenomenów. Od

\footnotetext{
${ }^{3}$ Hans Lenk, Interpretationskonstrukte. Zur Kritik der interpretatorischen Vernunft (Frankfurt/Main: Suhrkamp, 1993).

${ }^{4}$ Por. Ludwig Wittgenstein, Dociekania filozoficzne, tłum. Bogusław Wolniewicz (Warszawa: Wydawnictwo Naukowe PWN, 2000), \$23.
} 
dawna dyskutuje się o tym w psychologii. Czy hipotezy, które, co zrozumiałe, nie muszą być psychologicznymi „prawami” w naukowym sensie, zastępują eksplikacje, które znamy z bardziej ścisłych nauk? Albo jeśli należałoby ulokować te hipotezy po stronie danych wrażeniowych, to czy to oznacza, że psychologiczna teoria musi używać innych praw, że może ona co najwyżej brać za podstawę „osobiste teorie” bądź - w aspekcie opisowym - „dane” (jako wyobrażenia przypisywane odpowiednim podmiotom, które należy opisać)? Nie chcę tu rozwijać żadnej szczegółowej naukowej teorii psychologii ${ }^{5}$. Podkreślę tylko, że rozwinięte personalne konstrukty interpretacyjne ${ }^{6}$, co zrozumiałe, są w wysokim stopniu dopasowane do osobowych nastawień i interesów. Sprowadzają się do kontekstów osobistego, społecznie zapośredniczonego doświadczenia, w pewnych okolicznościach są silnie modyfikowane w sposób specyficzny dla danej sytuacji; nie obowiązują więc powszechnie, nie są też sformułowane w postaci teoretycznej - jak na przykład teorie w naukach przyrodniczych. Podmiot używa strukturyzujących wzorców, by z jednej strony interpretować swoje zachowanie wobec drugiej osoby, za każdym razem w innej w szczegółach sytuacji, a z drugiej strony - by je też zorganizować w sensie planowania, decydowania, działania, sterowania, kontrolowania itd. Podmiot potrzebuje ponadto odpowiedniego wzorca, by wyjaśniać, opisywać, ujmować, przewidywać lub przeczuwać zachowanie innych osób w odniesieniu i w analogii do siebie samego. Można tu dostrzec podobieństwo (w znaczeniu abstrakcyjno-metodologicznym) do postępowania, jakie jest typowe dla nauk społecznych czy psychologii, nawet jeśli subiektywne wyjaśnienia nie mogą zgłaszać roszczeń do powszechnej ważności, a nawet do względnej precyzji. Jednakże w pewnym sensie takie schematy różnią się od „naiwnych” teorii codzienności jedynie co do stopnia. Powyższy wywód podkreśla znaczenie strukturyzującej aktywności nie tylko w procesie poznawczym, lecz również w formowaniu normatywnej koncepcji działania.

\footnotetext{
${ }^{5}$ Por. Hans Lenk, Bewusstsein, Kreativität und Leistung (Darmstadt: WBG, 2007); tenże, Bewusstsein als Schemainterpretation (Padeborn: Mentis, 2004).

${ }^{6}$ Kelly stworzył w latach 50-tych psychologię personalnych konstruktów (Personal Construct Theory), która opisywała człowieka jako istotę konstruującą hipotezy w sensie badacza codzienności. „Naiwne teorie”, zwłaszcza jako „materiał” wykorzystywany w naukowym tworzeniu hipotez psychologicznych lub też jako materiał wykorzystywany w tworzeniu psychologicznych materiałów, omawia Uwe Laucken, Naive Verhaltenstheorie (Stuttgart: Klett Verlag, 1974).
} 
Takie ujęcie jest sprzeczne $\mathrm{z}$ antycznym wzorem i obrazem poznania, znanym $\mathrm{z}$ historii filozofii, zgodnie z którym sądzi się, że myślenie i poznanie polegają po prostu na widzeniu za pomocą „oka duszy”. Ta metafora, której szacowne pod względem filozoficznym źródła sięgają Platona („idea” i „teoria” pochodzą od „widzenia” i „kontemplowania”) wywarła duży wpływ na zachodnią filozofię - wpływ zarówno pozytywny, jak i negatywny. Wniosła nie tylko głębokie poznanie, lecz również wielkie „zbłądzenia”, ponieważ z jej powodu nie uwzględniono w dostatecznym stopniu praktycznej, eksperymentalnej, opartej na próbach i testach konfrontacji $z$ otaczającym światem 7 . (Później abstrakcje były „widziane” według wzoru rzeczowych obiektów). Zbyt długo, zwłaszcza w filozofii (i jeszcze długo po Galileuszu), trzymano się Platońskiej metafory poznania jako widzenia „okiem duszy”, a zbyt rzadko operowano w kontekście poznania konceptem aktywnego bytu działającego (na przykład eksperymentującego). Wewnętrznego związku poznania z działaniem nie zauważano czy nie tematyzowano w sposób wystarczający - co dotyczy zarówno działania, które zmaga się ze światem zewnętrznym, jak i działania strukturyzującego: „wewnętrznego” działania rozumianego jako schematyzowanie, świadome nabywanie orientacji i porządkowanie na bazie określonych, konceptualnych dyrektyw lub konstrukcji o charakterze wzorcowym i modelowym.

Przez długi czas nie uwzględniano zatem w poznaniu w dostateczny sposób momentu konstruktywnego i aktywno-dynamicznego. Metodologiczne założenie schematyzacji ma naturalnie tę zaletę, że ów aspekt poznania lokuje na pierwszym planie, ogranicza metaforę czystego „widzenia”, a jednocześnie przekracza widoczną w tradycyjnych ujęciach lukę pomiędzy poznaniem a działaniem.

Dzisiaj znamy pewne procesy, które kształtują zespoły neuronów na podstawie Hebbowskich reguł uczenia się: stabilizującej, powtarzanej aktywacji synaps, a również zgodnie z kształtowaniem się sieci neuronów i tak zwanych „zespołów neuronów" za pośrednictwem powtarzania wspólnej aktywacji. Dany jest przez to niejako quasi przyrodoznawczy obraz, który można również ująć jako kluczowy element procesów tworzenia i stosowania schematów. (Dochodzą do tego jednak

${ }^{7}$ To wszystko odnosi się również do rozwoju antycznej i średniowiecznej nauki - w naukach humanistycznych i częściowo również w nowożytnej Science. Wiemy, że eksperymentalna nauka zasadniczo dopiero w nowożytności (od Galileusza) osiągnęła pełną dojrzałość. 
wyższe poziomy „znaczenia”, intencjonalnego wskazywania itd.). Możemy przynajmniej powiedzieć tyle, że nawet jeśli potrzeba byłoby o wiele bardziej precyzyjnej pracy neuropsychologicznej i neurobiologicznej, to i tak w procesach transmisji (lub ich neuronalnych korelatach) udało się nam ustalić jakiś rodzaj podstawowego wzorca, który wskazuje, jak można sobie wyobrażać schematyzację.

Możemy więc, przykładowo, w przekonujący sposób pokazać, jak określone schematyzacje, opisywane w psychologii poznawczej, mogły zostać wdrożone na poziomie neuronalnym. Naturalnie, nie rozwiązuje to jeszcze problemu, jak wypełnić lukę między semantyczną zdolnością do tworzenia znaczeń, jaką przejawia instancjalizacja schematu a - powiedzmy - prostą i powtarzaną, stałą aktywacją względnie ustabilizowanych zespołów neuronów. A zatem, w jaki sposób od fizjologicznych procesów neuronalnych przechodzimy do znaczenia? Jest to centralna kwestia związana $\mathrm{z}$ mentalną reprezentacją, wielkie pytanie stawiane $\mathrm{w}$ ramach dyskutowanej współcześnie problematyki duszy i ciała, w niemieckiej nowomowie nazywanej „problematyką mind-brain”.

Najpierw przejdę do psychologii schematów, to znaczy do psychologii poznawczej traktującej o teorii schematów. Chciałbym tu tylko powtórzyć to, co na ten temat mówiłem w moich wcześniejszych publikacjach ${ }^{9}$, zwłaszcza na przykładzie najlepszej, najbardziej przejrzystej pracy z zakresu psychologii schematów, Davida Rumelharta Schemata - the Building Blocks of Cognition ${ }^{10}$. Jego główna teza głosi, że schematy przedstawiają naszą wiedzę i służą do jej strukturyzowania - nie tylko do jej magazynowania w pamięci, lecz pozwalają również sytuować wiedzę w każdorazowych kontekstach oraz tworzyć jej każdorazowe reprezentacje. Wszelkie akty poznawcze, postrzeżenia, interpretacje mają do czynienia z wyzwalaniem, wyborem lub stosowaniem, jak i ze sprawdzaniem schematów, a zatem z utwierdzeniem, z kształtowaniem schematów oraz ich stosowaniem wzgl. ich reaktywacją. Proces interpretacji polega w ogólności na tym, że możliwe kon-

\footnotetext{
${ }^{8}$ Por. Hans Lenk, Das Denken und sein Gehalt (Oldenbourg: München, 2001); tenże, Denken und Handlungsbindung (Freiburg: Karl Alber, 2001); tenże, Kleine Philosophie des Gehirns (Darmstadt: WBG Primus, 2001); tenże, Bewusstsein als Schemainterpretation (Paderborn: Mentis, 2004).

9 Por. np. tenże, Interpretationskonstrukte, tenże, Schemaspiele (Frankfurt/Main: Suhrkamp, 1995); tenże, Bewusstsein als Schemainterpretation.

${ }^{10}$ Por. David E. Rumelhart, Schemata. The Building Blocks of Cognition, CHIP Report 79 (San Diego: Center for Human Information Processing, University of California, 1978).
} 
figuracje schematów podlegają wyborowi, a następnie sprawdzianowi, że są używane i instancjalizowane ze względu na to, czy zgadzają się z określonymi wrażeniami pamięciowymi lub danymi jakiegoś fragmentu pamięci, które są selektywnie sterowane z uwagi na cechy, bądź też czy zgadzają się z odpowiednimi zewnętrznymi wrażeniami zmysłowymi. Również Neisser ${ }^{11}$ tworzenie i konstytuowanie schematów jednoznacznie zalicza do tej interpretacyjnej aktywności, podczas gdy Rumelhart nie dyskutuje tego explicite. Ale obaj mają jasność co do tego, że proces ten polega na aktywnym poszukiwaniu (eksploracji) i strukturyzowaniu informacji, które łączy się z naszymi aktualnymi potrzebami i celami (za każdym razem w istotny sposób), ale również z pamięcią. Gdy czyta się Neissera ${ }^{12}$, nieuchronnie przychodzi na myśl badane przez etologów zachowanie apetencyjne. Polega ono na tym, że organizm jest zawsze aktywny i poszukuje bodźców wyzwalających, przeszukuje otoczenie pod kątem tego, czy określone bodźce wyzwalające lub określone informacje są dlań interesujące bądź też czy odpowiadają preferowanym przezeń celom - na przykład w trakcie szukania pożywienia, partnera lub podczas innych działań służących przetrwaniu. Neisser ${ }^{13}$ dyskutuje na przykład płynne modele takiego procesu schematyzowania, w których ważną pozycję zajmuje eksploratywne, poszukujące zachowanie w otoczeniu, dostarczające pobudek do strukturyzowania pozyskanych sygnałów lub do tworzenia i wyzwalania odpowiednich specyficznych schematów, a zatem prowadzące do ustanowienia określonego aktywnego porządku, a nawet wyzwalające określone sprzężenia zwrotne, które wzmacniają lub kontrolują trafność.

W tym sensie tworzenie i stosowanie schematów odbywa się w ramach pewnego rodzaju procesu eksplorująco-strukturyzującego, jest interpretacją bądź interpretacyjną aktywnością. Interpretowanie w tym szerszym znaczeniu jest zatem kształtowaniem, aktywowaniem i użyciem schematów.

Dlatego psycholodzy mówią o „schematach” jako określonych strukturach wiedzy lub informacji, służących reprezentacji gatunkowych pojęć, najczęściej

${ }^{11}$ Ulric Neisser, Kognition und Wirklichkeit (Stuttgart: Klett-Cotta, 1979).

${ }^{12}$ Por. Ulric Neisser, Kognitive Psychologie (Stuttgart: Klett-Cotta, 1974); tenże, Kognition und Wirklichkeit. Prinzipien und Implikationen der kognitiven Psychologie (Stuttgart: Klett-Cotta, 1996).

${ }^{13}$ Tenże, Kognition und Wirklichkeit. 
zmagazynowanych w pamięci ${ }^{14}$. Używa się tu różnych pojęć, takich jak „struktura schematu”, „wzorzec”, „ramy”, „konstrukt”, „raster”, „schemat pojęciowy”, „konfiguracja”, a niekiedy nawet „strategia” lub w tradycyjnej filozofii „konstytucja”, „synteza” lub „kreatywna synteza”.

Wszystkie te pojęcia są mętne, jedynie opisują coś, czego, oczywiście, nie ujęliśmy jeszcze „w pojęciu”, co jednak wiąże się z tą schematyzującą aktywnością i w zasadzie może być przedstawione tylko w przybliżeniu za pośrednictwem mozolnych opisów językowych. Nie istnieje zatem żadna rzeczywiście precyzyjna, wyraźnie wyartykułowana, wolna od jakiegokolwiek błędnego koła definicja pojęcia „schemat”. Psycholodzy przechodzą najczęściej natychmiast do punktu, w którym przestają myśleć o definicji, a jedynie używają pojęcia, że tak powiem, ilustrując je za pomocą przykładów i instancjalizacji. Teorię schematów - zatem jej ideę - można rozjaśnić (tylko) za pośrednictwem zastosowania schematu. Funkcjonowanie schematu staje się dzięki temu bardziej plastyczne i zrozumiałe, co ma tę zaletę, że pojęcie „schematu” i teoria schematów zostają w pewnym sensie wyraźniej przedstawione $w$ działaniu. Równocześnie szczególnie wyeksponowany zostaje moment konstruktywny, rasterowanie, konkretyzacja aktywności, strukturyzowanie działań zwłaszcza w aktach tworzenia reprezentacji. Interpretacje schematów i konstrukty interpretacyjne są systematycznie powiązane ze sobą: bez schematyzacji nie ma interpretacji konstruktów, które muszą być ponownie przywoływane w akcie rozumienia i odgraniczania efektów schematyzacji - przynajmniej na metapłaszczyźnie hipotetycznych opisów. Wszystko, co przyniosły badania na temat wdrażania i wprowadzania w sytuacje pewnych schematów, uczenia się i nauczania bądź badania dotyczące ustabilizowanej przez nawyki reaktywacji i rozpoznawalności schematów i konstruktów interpretacyjnych lub ich zastosowania, daje się, rzecz jasna, odnieść do koncepcji gier schematami bądź do gier interpretacjami schematów, bez konieczności przeprowadzenia dalszych wyjaśnień.

${ }^{14}$ To naturalnie nie jeszcze jasne, ponieważ nie wiemy dokładnie, czy sama struktura jest informacją, czy też strukturą informacji w tym sensie, że przetwarza informacje? Czy reprezentowanie jest procesem, czy stanem zaistniałym za pośrednictwem procesu reprezentacji? Jak odnosi się ten stan do struktury informacji, a zwłaszcza w jak sposób proces reprezentacji może porządkować strukturę informacji? Wszystkie wspomniane kwestie są wciąż nieprecyzyjne, mętne i sformułowane jedynie metaforycznie. 
Korzyść z takiej ogólnej perspektywy jest taka, że przynajmniej pozwala dostrzec możliwość przerzucenia mostu pomiędzy dyscyplinami przyrodoznawczymi odwołującymi się do neuroreprezentacji, z jednej strony, a brzemiennymi semantycznie koncepcjami znaczenia nauk humanistycznych $\mathrm{z}$ drugiej strony. Ponadto płynie stąd taka korzyść, że w ramach filozofii poznawczej i neurofilozofii zostają zrehabilitowane zewnętrzne, werbalno-behawiorystyczne "gry” słowami i wyrażeniami (łącznie z ich osadzeniem w sferze działania). Naturalnie, jest to nadal w znacznej mierze jedynie postulowana, hipotetyczna muzyka przyszłości. Z drugiej strony, nowsze, operujące rzeczywistymi przebiegami czasowymi, nieinwazyjne metody - służące do badania przebiegów poznawczych i procesów myślowych - dają możliwość „przerzucenia mostu” nad wspomnianą luką oraz służą do połączenia, a przynajmniej do sformułowania interesującej i owocnej dla przyszłych badań paraleli. Wszystkie te procesy formowania i strukturyzowania stają się szczególnie wyraźnie dzięki prawidłowości, którą można prześledzić za pomocą - niemal już klasycznej - teorii Rumelharta.

Rumelhart pisze: „cała wiedza jest osadzona w schematach i przez nie zorganizowana: nasze schematy są naszą wiedzą" ${ }^{15}$. Jednakże schematy są oczywiście o wiele bardziej ogólne; obejmują również strukturyzacje działań, nie są zatem tylko wiedzą pojęciową, werbalną czy propozycjonalną. W schematy należałoby przynajmniej włączyć „wiedzę praktyczną” (umiejętności, know-how). W pewnym sensie, wiedzę rozumiano tradycyjnie nazbyt teoriopoznawczo i ujmowano ją w zbyt pasywnych kategoriach. Każda formująca strukturyzacja, każda schematyzująco-interpretująca aktywność - również taka, która wykracza poza wiedzę kognitywno-reprezentującą - jest poddana schematyzacji, podlega schematom, przebiega $\mathrm{w}$ ich obrębie; i w tym stopniu schematy muszą również sięgać poza obszar wiedzy. Ale słuszny jest także pogląd, że wszystko, co możemy rozumieć poprzez „wiedzę”, myślenie, reprezentację myśli, wyobrażenia, treści oraz intencjonalne treści lub przedmioty wyobrażeń, jest ukształtowane przez schematy, przez nie uformowane i właśnie „uschematyzowane”- a zatem wyselekcjonowane i ustrukturyzowane pod kątem cech typowych. Poza działaniami, sytuacjami i formami życia, wydarzeniami, przedmiotami w uschematyzowaną formę możemy

\footnotetext{
${ }^{15}$ Rumelhart, Schemata.
} 
przenieść również relacje przestrzenne, statyczne i wszystkie inne. Schemat przestrzennej postaci można dostrzec bezpośrednio, i tak też się mówi w życiu codziennym. Wystarczy choćby pomyśleć o wzorach gwiazdozbiorów. Rumelhart porównuje funkcje schematów do funkcji scenariuszy aktorskich, do funkcji teorii bądź systemów hipotez, programów komputerowych i lingwistyczno-gramatycznych analiz składników tekstów.

Schematy nie przedstawiają wszystkich szczegółów, każdego detalu, który stanowi przedmiot przeżycia reprezentującego lub postrzegającego, lecz dokonują wyboru, selekcjonują. Dlatego Rumelhart podkreśla, że „teoria schematów” obejmuje „również teorię przypisywania znaczenia (Bedeutungzuordnung), znaczenia językowego, w tej mierze, w jakiej schemat leżący u podłoża pojęcia, tak jak jest zmagazynowany w pamięci, jest znaczeniem tego pojęcia, które należy scharakteryzować za pomocą odpowiednich cech, lub też które odpowiada znaczeniu tego pojęcia. Uschematyzowane cechy, charakteryzujące schemat, odpowiadają znaczeniu odpowiedniego pojęcia. Można to rozumieć przedjęzykowo; istnieją też przecież przedjęzykowe, choć pojęciowe zdolności rozróżniania, przyporządkowywania na podstawie podobieństw. Ale to, co zostało wypowiedziane, może, rzecz jasna, w normalnych sytuacjach odnosić się również do schematyzacji, które dopiero za pośrednictwem języka mogą być dokładniej określone. Cechy zawężają zakres znaczeniowy pojęcia. Odpowiedni schemat zostaje wówczas zindywidualizowany, zinstancjalizowany w określonych, istotnych sytuacjach. Schemat może być wywołany, aktywizowany i również odniesiony do innych schematów, jako ich podrzędny lub nadrzędny schemat (Oberschema) ${ }^{16}$. Według Rumelharta, znamienne jest to, że zarówno schematy, jak i teorie wykazują zmienne, które wiążą się z rozmaitymi aspektami otoczenia pod względem każdorazowego, konkretyzującego zastosowania, instancjalizacji schematu. Naturalnie, zmienne mogą być również ograniczone do danego obszaru, są też problemy związane z wartością brzegową i początkową. Szczegółowy przypadek trzeba sprowadzić do bardziej

\footnotetext{
${ }^{16}$ Ważne jest, że schematy przedstawiają każdorazowo całą hierarchię składającą się z subschematów, przyporządkowanych schematów pobocznych i nadrzędnych nad- lub superschematów. Można je ująć w określone sieci-schematów, w siecio- lub drzewopodobnym całościowym porządku - często również w porównaniu; a to naturalnie można byłoby sprowadzić do analogii ze schematami decyzyjnymi lub schematami blokowymi. W schematach pojęciowych lub hierarchizacjach można znaleźć hierarchiczną strukturę schematycznych powiązań.
} 
ogólnego wzorca; tak jak w teoretycznych wyjaśnieniach lub uogólnionych pojęciowo ujęciach pojedynczych przypadków.

Przyjrzyjmy się przykładowi, który Rumelhart przećwiczył aż po najdrobniejsze szczegóły. Chodzi o schemat SPRZEDAWANIA, który sytuacyjne konotacje czy też formy życia, takie jak „kupowanie” i „sprzedawanie”, sprowadza do odpowiadającego im ogólnego wzorca, przedstawiając niejako schemat, który automatycznie lub quasi-automatycznie jest wywoływany i aktywizowany: przykładowo, gdy słyszymy słowo „sprzedawać”, wiemy, że chodzi o określoną, znaną nam sytuację. Rzecz jasna, nie jest to wcale sytuacja „naturalna”, lecz ukształtowana kulturowo, instytucjonalnie i przez tradycję. (Są tubylcze plemiona - jak Indianie Zo'é, którzy zostali niedawno odkryci i nigdy wcześniej nie mieli kontaktu z tzw. cywilizacją - które w ogóle nie znają takiej instytucji czy formy życia i działania, jak „kupowanie” i „sprzedawanie”, choć być może znają ogólny schemat „wymiany” naturalnych produktów. Schemat SPRZEDAWANIA wiąże się, oczywiście, $z$ innym podschematem: muszą bowiem istnieć sprzedawcy i kupcy, którzy realizują i znają! ten sam schemat. Poza tym muszą istnieć określone, skonwencjonalizowane i zinstytucjonalizowane formy wymiany, na przykład pieniądza, które regulują sprzedaż: na przykład wymiana za pośrednictwem pieniądza, taka jest bowiem definicja „kupowania” i „sprzedawania”. Możemy przynajmniej stwierdzić w tym kontekście, że aby móc SPRZEDAWAĆ, należy najpierw założyć ogólny nadrzędny schemat, powiedzmy schemat WYMIANY. Natychmiast wówczas rozumiemy, że obok niego istnieje ustalony, równoważny z nim i przez to bezpośredni, niemal analitycznie z nim powiązany schemat KUPOWANIA. „Sprzedawanie” i „kupowanie” należy rozumieć łącznie, ponieważ są to pojęcia wymienne - podobnie jak „podmiot“ i przedmiot“. Są odniesione do siebie bezpośrednio w procesualno-analityczny sposób, są definiowane pod kątem wzajemnego odniesienia. Następnie musi też istnieć schemat tego, co dla kupowania i sprzedawania jest dobrem, a zatem co jest towarem. Schemat TOWARU jako schemat reprezentacji tego, co jest sprzedawane i kupowane, musi dotyczyć również subschematu „negocjowania”, „oferty” i „porozumienia” lub „odrzucenia”, „podaży i popytu” itp. To znaczy, ów proces negocjowania, „działania” (np. negocjowania przy robieniu interesów) jest schematem częściowym, schematem działania, którego opanowanie jest oczekiwane i charakteryzuje się określonym oczekiwaniem co do ról, tzw. normami (jak mówią socjolodzy). Zatem teza, że taki 
schemat jak np. SPRZEDAWANIE, odsyła do określonych schematów podrzędnych, schematów pobocznych, ale również schematów nadrzędnych, które razem z odpowiadającymi im funkcjonalnymi rolami są za każdym razem równocześnie współaktywizowane. Wraz z nadrzędnym schematem SPRZEDAWANIA wyobrażamy sobie subschematy bądź też są one wraz nim współaktywizowane. Te zaś przyjmujemy w wyobraźni jako współdane lub współreprezentowane. Kiedy chcemy coś sprzedać lub kupić, wiemy, jak mamy się obchodzić z towarem, wiemy, czym jest „towar” i czego chce kupujący. A przynajmniej sytuacja sprzedaży i kupowania jest $\mathrm{w}$ określony sposób wyodrębniona instytucjonalnie. Wiemy, że obydwa działania pasują do warunków panujących na rynku lub w sklepie. Dzięki temu staje się jasne, że w tym właśnie, a nie w innym miejscu można sprzedawać i kupować.

Rumelhart pisze o tym ogólnie: „schemat zostaje zinstancjalizowany, gdy tylko konfiguracja wartości zostanie przyporządkowana do określonego punktu czasowego w określonej kombinacji, określonej konfiguracji zmiennych"17. Interpretacja sytuacji jako instancji jakiegoś pojęcia zawiera instancjalizację pasującego doń schematu, na przykład schematu KUPOWANIA, poprzez to, że rozmaite zmienne schematu zostają powiązane z różnymi aspektami sytuacji. Taki schemat wraz ze zmiennymi nazywa się wówczas „zinstancjalizowanym schematem” (podkr. H. L.). To oznacza, że schemat zostaje odniesiony do określonej osoby, aktora społecznego, okoliczności, sytuacji, kontekstów itd., a zatem że zostaje zrealizowany, skonkretyzowany, właśnie zinstancjalizowany i użyty do pasującej sytuacji w pojedynczym przypadku. Uwzględniamy pojedynczy przypadek, specyfikujemy, konkretyzujemy, a następnie dopasowujemy ogólny schemat do cech owego przypadku i sytuacji, w jakiej się on pojawia. W ten sposób, ogólny schemat i przyporządkowane mu subschematy strukturyzują wstępnie sytuację najpierw w ogólnych zarysach i w pewnej perspektywie, a następnie specyfikują ją i konkretyzują. Można to sobie wyobrazić w analogii do postępowania w tradycyjnej teorii nauki, w którym wyjaśnianie odwołuje się do ogólnych praw. W teorii nauki dysponujemy ogólnym prawem, związkiem struktur, który podlega założeniom regulującym opis pojedynczego przypadku, tzw. warunkom początkowym lub syn-

\footnotetext{
${ }^{17}$ Tamże.
} 
gularnemu eksplanasowi (syngularnym przesłankom czy założeniom eksplanacji). Następnie, poprzez zastosowanie pojedynczego opisu, bądź za pośrednictwem specyfikacji w ramach ogólnego twierdzenia (prawa) wyprowadza się w logiczno-dedukcyjny sposób twierdzenie końcowe, eksplanandum. Takie przypadki można sobie wyobrazić również w schematyzacjach, choć, rzecz jasna, chodzi tam najczęściej o pojedynczą instancjalizację, a nie o logiczną dedukcję z uniwersalnych praw natury; chodzi zatem o ścisłą i sprawdzalną konkluzję, jak w prognozach naukowych lub wyjaśnieniach dedukcyjno-nomologicznych. Schemat KUPOWANIA musi jednak pasować do każdego pojedynczego przypadku kupowania.

Suma schematów służących do interpretacji naszego świata, powiada Rumelhat, stanowi naszą "prywatną teorię“ „rzeczywistości”, „natury rzeczywistości”, stanowi nasze ujęcie (własnego) „świata przeżywanego”. Zinstancjalizowane w określonym punkcie czasowym schematy stanowią reprezentowany i zrealizowany model każdorazowej sytuacji, który jest konstruowany lub konkretyzowany w ramach danych, stojących do dyspozycji schematów. Schematy nie reprezentują jednak tylko wiedzy, lecz również strukturyzacje normatywnei wiedzę praktyczną (know-how), służą również do strukturyzowania wszelkich możliwych sposobów zachowania się i działania w obcowaniu ze światem zewnętrznym, ze społecznymi partnerami itd. To samo, rzecz jasna, odnosi się do odpowiedniego strukturyzowania reprezentacji „wewnętrznych” (mentalnych), wyobrażeń, które sobie tworzymy. Schematy nie reprezentują zatem tylko wiedzy, lecz również „ujęcia“ na wszelkich płaszczyznach abstrakcji; formują je, są raczej aktywnymi procesami lub procedurami, aniżeli strukturami statycznymi, posiadają jednak pewną względną (dynamicznie wzmocnioną) stabilność; można je rozpoznawać, zakładają bowiem zapis w pamięci i możliwość ponownego wywołania. Można je oceniać i osądzać z uwagi na ich zastosowanie i przetwarzanie, ze względu na to, w jakim stopniu są przydatne do opisu sytuacji lub ujęcia innych informacji, które należy przetworzyć. Ogólnie rzecz ujmując, schematy stanowią struktury przetwarzania na wszelkich płaszczyznach abstrakcji, począwszy od (u)porządkowania percepcji po teoretyczne ujednolicenie danych oraz ich praktyczną strukturyzację, choćby w sensie wstępnej koncepcji, antycypacji w planowaniu itd. Można powiedzieć, że kognicja w ogólności jest konstrukcją i zastosowaniem schematów (dotyczy to odpowiednio każdego uregulowanego działania). Każdy rodzaj reprezentacji - czy 
będzie to zewnętrzna, czy „wewnętrzna” bądź mentalna reprezentacja - jest w tym sensie „konstrukcyjny”, jest zastosowaniem schematów do ich instancjalizacji za pośrednictwem zespołu danych, który należy specyficznie ująć, wzgl. ich zastosowaniem do danej sytuacji. W każdym przypadku chodzi zatem o schematy zinstancjalizowane lub o dające się instancjalizować uschematyzowane konstrukty, konstrukty schematów lub „konstrukty interpretacji” - jeśli to sformułować za pomocą używanych tu wyrażeń. Bez schematyzacji, bez konstruktów interpretacyjnych nie ma wiedzy, działania, poznania lub „ujęcia“ "sytuacji ${ }^{18}$; jest to podstawowa w istocie zasada metodologiczna: wszelkie poznanie, każdorazowe działanie jest ostatecznie związane z interpretacją, jest ukształtowane przez schematyzacje i odpowiednie rezultaty procesów schematyzowania, tj. przez rezultaty konstruktów interpretacji (schematów). Tak można rozumieć centralną funkcję tworzenia i zastosowania schematów w ujmowaniu, porządkowaniu, kształtowaniu, porównywaniu zdarzeń, przedmiotów i sytuacji oraz ich reprezentantów za pośrednictwem interpretacji. Naturalnie, to samo dotyczy też instancjalizacji pasujących schematów działania, ich kontroli i zwrotnej kontroli w użyciu oraz w ich prawdopodobnie koniecznej zmianie. Warianty tych sposobów ujmowania lub też aktywność, którą należy „schematycznie“ interpretować, można zilustrować w następującym przeglądzie ${ }^{19}$.

18 „Ujęcie” („Erfassung”) obejmuje zarówno aktywny moment „ujmowania” („Fassen”), jak i pasywny moment w przenośnym znaczeniu. Por. Hans Lenk, Erfassung der Wirklichkeit (Würzburg: Königshausen \& Neumann, 2000); tenże, Grasping Reality (Singapore: World Scientific, 2003).

${ }^{19}$ Por. poniższy załącznik oraz krótką prezentację w formie tekstu komentującego przedstawiony diagram. Por. Hans Lenk, Interpretationskonstrukte, 56. Lekko zmodyfikowana wersja np.: tenże, Bewusstsein als Schemainterpretation, 75 i n. Odnośnie do płaszczyzn i stopniowania (konstruktów) interpretacyjnych por. załącznik. Por. Lenk, Interpretationskonstrukte, 109; tenże, Bewusstsein als Schemainterpretation, $74 \mathrm{i}$. 


\section{Aktywność interpretacyjno-schematyzująca: Interpretacje (za pośrednictwem schematów)}

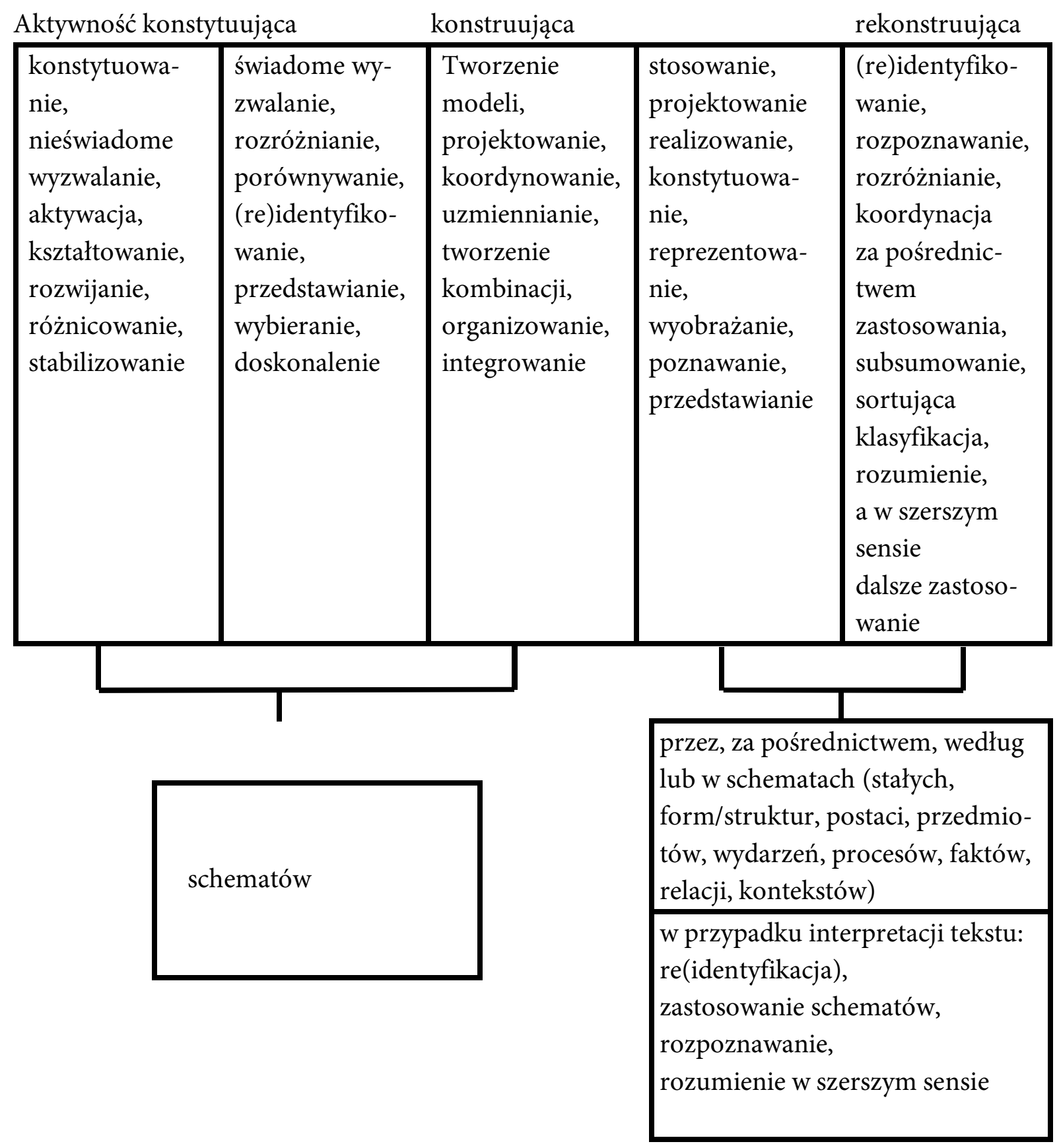




\section{Gry językowe - formy życia - gry schematami}

Jak wiadomo, Ludwig Wittgenstein nie zdefiniował precyzyjnie pojęcia "gra językowa”, lecz tylko zilustrował je na przykładach ${ }^{20}$ powiązanych ze sobą "rodzinnym podobieństwem”) ${ }^{21}$. Wittgenstein chciał w istocie podkreślić, że „mówienie jest częścią pewnej działalności, pewnego sposobu życia"22, a więc że językowe wyrażenia, tym samym ich rozumienie, są osadzone w kontekstach działania i formach życia. Wittgenstein zaznacza wyraźnie, że grą językową nazywa: „całość złożoną z języka i z czynności, w które jest wpleciony”23. Te gry językowe są właśnie „odgrywane”, a więc można je - podobnie jak obejmujące je formy życia oraz związane z działaniami wdrożone nawyki - po prostu uznać, przyjąć oraz „opisać” „w” ich użyciu i „poprzez” ich użycie. Według Wittgensteina, zadanie filozoficznego opisu polega w istocie na tym, by rozpoznać, ustalić i właśnie zauważyć grę językową w jej uwikłaniu: „Ta gra językowa jest odgrywana” ${ }^{24}$. Przy tym za każdym razem „zastosowanie pozostaje nadal kryterium rozumienia”25. Znaczenie słów i werbalnych części gier językowych jest wyuczone, pokazane, zrozumiane poprzez użycie bądź w kontekstach działania, w obrębie form życia ${ }^{26}$ : „Tym, co po prostu trzeba przyjąć, co jest dane, są - można rzec - sposoby życia"27.

Wittgensteinowska koncepcja gier językowych jest bardzo płodna, gdy chodzi o ogólne osadzenie językowych reprezentacji w kontekstach działania i formach życia, ale wskazuje ona również na bardziej ogólne perspektywy, które można odnieść do mentalnych reprezentacji, interpretacji schematów itd.; ponie-

${ }^{20}$ Przy czym do gier językowych Wittgenstein zaliczył również „sporządzanie przedmiotu wedle opisu (rysunku)”, a nawet „przedstawienia teatralne”, jak i „rozwiązywanie zwykłych zadań rachunkowych”, „snucie domysłów na temat zajścia”, „przedstawianie wyników eksperymentu za pomocą tabel i wykresów".

${ }^{21}$ Wittgenstein, Dociekania filozoficzne, $₫ 23, \S 67$.

${ }^{22}$ Tamże, $\$ 23$.

${ }^{23}$ Tamże, $\$ 7$.

${ }^{24}$ Tamże, $\$ 154$ i n.

${ }^{25}$ Tamże, $\$ 146$.

${ }^{26}$ Tamże, $\$ 43$.

${ }^{27}$ Tamże, 317. 
waż szereg wyżej wymienionych oraz także innych przykładów odnosi się w istocie do schematyzująco-interpretacyjnych aktywności w pewnych sytuacjach ${ }^{28}$, które mogą być rozumiane w funkcjonalnym aspekcie interpretacji. Zwłaszcza dotyczy to reguł użycia, rozumienia znaków itd.

To przekonujące rozszerzenie oraz rozumiane zgodnie ze znaczeniem Wittgensteinowskim praktyczne osadzenie "gier językowych" (zresztą również użycia obrazów i znaków) jest z pewnością słuszne i nadzwyczaj ważne, gdyż w ten sposób można w grach językowych uniknąć błędnego ograniczenia do gier czysto werbalnych i rozwinąć bardziej ogólnie funkcjonalistyczną teorię zastosowania procedury reprezentacji bądź też odpowiednich środków reprezentacji. Jednakże to uogólnienie jest mylące przede wszystkim w wymiarze działań zewnętrznych, w kontekście quasi behawiorystycznym, gdy ogranicza się do zewnętrznych mediów i nośników reprezentacji oraz ich zastosowania. Oczywiste jest, że takie uogólnienie nie może być wystarczające. Spostrzeżenie to można rozszerzyć na »obrazy « w zewnętrznym, mentalnym i wirtualnym lub wręcz imaginacyjnym sensie, ale wówczas należy je ograniczyć za pomocą odpowiednich reprezentacji mentalnego rodzaju, które odpowiadają - tradycyjnie określanym jako „wewnętrzne” reprezentacjom, symbolom, identyfikacjom i ogólnym konstrukcjom, jak i rekonstrukcjom rozumianym jako interpretacja schematów. Chodzi zatem o socjokulturowe, relatywne ustalenie stanu rzeczy poprzez wdrożenie schematu, o unormowanie i osadzenie reprezentacji poprzez językowe sformułowania, ale również poprzez wewnętrzne „mentalne” reprezentacje, które, rzecz jasna, mogą i muszą być rozumiane funkcjonalnie i zgodnie z teorią użycia jako przyporządkowanie znaczeń zachodzące w przypadku zewnętrznych symboli. Wspomniane prawidłowości obowiązują przynajmniej w perspektywie metodologicznej lub, gdy uwzględnimy możliwość sprawowania kontroli, gry schematami dają się częściowo - ale tylko częściowo! - ująć jako uwewnętrznione gry językowe à la Wittgenstein i Sellars ${ }^{29}$.

\footnotetext{
${ }^{28}$ Patrz powyższy diagram. Por. Lenk, Interpretationskonstrukte; tenże, Philosophie und Interpretation (Frankfurt/Main: Suhrkamp, 1993); tenże, Schemaspiele.

${ }^{29}$ Dotyczy to nawet prewerbalnych gier związanych z oddziaływaniem na pozornie niezależnie od nas istniejące, zewnętrzne przedmioty - samo budowanie relacji odnoszenia, referencji jest interpretacyjnym postępowaniem. Można to stwierdzić w odniesieniu do procesów i rezultatów „wewnętrznego” fenomenu domniemywania, a zatem do wewnętrznych interpretacji. Por. Lenk, Bewusstsein als Sche-
} 
Wittgenstein wskazuje na to wzajemne przenikanie się języka i interpretacji w kontekście problematyki uzasadnienia w Dociekaniach filozoficznych ${ }^{30}$, gdzie podkreśla, że zwyczajowe działania i formy życia nie są dane absolutnie, że możemy i musimy pragmatycznie wytwarzać wzgl. realizować społeczne zakorzenienie gier językowych, rezygnując $\mathrm{z}$ naszych uzasadnień. Wittgenstein sądzi, że w próbach uzasadnienia - mówiąc metaforycznie - „rydel” „Zwija się” na „twardej skale” rzeczywistych zwyczajowych działań i form życia ${ }^{31}$. Te jednak często podlegają znacznym zmianom, czy to w trakcie dokonywanych przez nas świadomie zmian, modyfikacji celów itd., czy to w interpretacji, w historycznym rozwoju naszych zwyczajowych interpretacji, czy to w rezultacie ogólnego, społecznego, historycznego rozwoju (na przykład technicznego postępu w medialnej komunikacji ogarniającej wszystkie kontynenty wraz z jego tendencją do sztucznie wytworzonej wszechwładnej „obecności”). Interpretowanie należy zatem postrzegać wodniesieniu do odpowiedniej praktyki i we wzajemnej obustronnej relacji zmiany i wpływu reprezentacji oraz innowacji działania.

To powiązane ze schematami interpretowanie jest w pewnym sensie działaniem, a działanie jest zawsze powiązane z wykładnią, jest „naładowane” semantycznie, ma więc naturę interpretacyjną. Jednakże również działanie może zmieniać interpretację i na odwrót: nasze zwyczajowe interpretacje oraz ich historyczny rozwój mogą zmieniać praktykę interpretowania - a w ogólności pewne społeczne praktyki, które potem stają się społeczną realnością; gdyż społeczna realność wyróżnia się przez to, że zawsze jest produktem interpretacji. W istocie ważne jest - a jak zobaczymy, podkreśla to również Wittgenstein - że interpreto-

\footnotetext{
mainterpretation. (Pozostaje jednak analogiczna możliwość ujęcia - w ramach teorii funkcjonalno-użytkowej - gier schematami, które nie są projektowane do „wnętrza”, a tym samym możliwość ujęcia, które uwzględnia wspomnianą problematykę społecznego zakorzenienia.)

${ }^{30}$ Wittgenstein, Dociekania filozoficzne, $\$ 217$.

${ }^{31}$ Sądzę, że jest to zbyt prosty obraz: rydel i skała nie są do siebie odniesione w tym sensie, że jedynie rydel musi ugiąć się na „twardej skale” - to jest nieco myląca metafora, „obraz”. Wittgenstein nieustannie podkreśla, że zbyt łatwo dajemy się zwieść „obrazom”. Wydaje mi, że w tym przypadku on sam dał się zwieść temu obrazowi, który skądinąd możemy zinterpretować nieco inaczej. Rydel i skała są odniesione do siebie pod względem swej twardości i zdolności do kruszenia. Należałoby więc nieco zmienić obraz: wówczas nie chodziłoby już o zbyt twardą skałę, lecz o dość twardą warstwę gleby, którą możemy jednak przekopać: skoro mamy możliwość dokonania reinterpretacji, możemy również zmienić naszą praktykę życiową.
} 
wanie na głębokim poziomie jest stale i nierozerwalnie związane $z$ uspołecznieniem: nie można wyłącznie prywatnie interpretować w dający się kontrolować, operacyjnie jednoznaczny sposób, gdyż interpretowanie jest zawsze powiązane z podstawową egzystencją, jak również ze zdolnością i możliwością wywierania wpływu ze strony danej wspólnoty interpretacyjnej, zakłada więc jako podstawę sytuację społeczną, a przez to także ustabilizowane, zwyczajowe działania międzyludzkie, obyczaje, normy i praktyki normowania. Można dzięki temu bez wątpienia udowodnić zasadniczo społeczne osadzenie pojęciowych ujęć, a także sposobów podążania za regułami oraz instytucji i opinii. Nie ma możliwości, byśmy mogli bez „obyczajów” (Wittgenstein) i zwyczajów, niezależnie od instytucji rozwijać się lub świadomie się uczyć bądź kontrolować zastosowanie i realizację procedur schematyzacji i interpretowania, tj. form lub reguł interpretacji. Interpretowanie schematów, a w ogólności interpretowanie jako takie, nie może być wyłącznie egocentryczne. Ponieważ wykracza poza wtórną egocentryczność interpretującego, należy je rozumieć jako zasadniczo i konstytucjonalnie społeczne, zasadniczo zewnętrzne wobec podmiotu lub wykraczające poza podmiot i właśnie dlatego należy je ujmować w kategoriach praktycznych, odnoszących się do codziennego działania, do panujących „obyczajów” ${ }^{32}$. Interpretowanie oznacza: trancendowanie ego/podmiotu ku temu, co społeczne. Usystematyzowana interpretacja jest zdana na takie transcendowanie, podobnie jak na metainterpretację. W tym sensie, interpretowanie jest ukonstytuowane na poziomie społeczno-symbolicznym, jest społeczno-symbolicznym transcendowaniem egocentryzmu.

Wraz z porzuceniem metodologicznego stanowiska, które zależy wyłącznie od eksternalistycznej [extern(alistisch)en] behawiorystycznej identyfikacji znaków, wraz z dostępnością (neurofizjologicznych korelatów) aktywacji schematów za pośrednictwem nieinwazyjnej metody neuronaukowej, możemy, z jednej

\footnotetext{
${ }^{32}$ To odnosi się również do interpretacyjnych schematów: nie istnieje żaden absolutny, niezależny od interpretacji fundament interpretowania, jakiś „fakt” lub „fakt nadrzędny”, do którego moglibyśmy odnieść się w uzasadniony sposób, aby ustalić jednoznacznie interpretacje lub je zdefiniować, lecz mamy tylko dwie możliwości: albo możemy wnikać w nieskończone odcienie interpretacji, a zatem w tym sensie „podejmować interpretację za interpretacją” (por. Wittgenstein, Dociekania filozoficzne, \$201), albo też możemy wycofać się w stronę teorii metodologiczno-epistemologicznych i rozróżniać rozmaite stopnie abstrakcji, różne płaszczyzny, typy, stopnie interpretacji (Por. Lenk, Interpretationskonstrukte, 56; tenże, Bewusstsein als Schemainterpretation, 75 i n.). Ponadto musimy wreszcie powrócić do społecznie akceptowanego przerwania naszych procesów interpretacyjnych, to znaczy, po prostu programowo kiedyś, gdzieś przerwać następujące po sobie wykładnie za pośrednictwem społecznego fiat.
} 
strony, quasi przyrodoznawcze zastosowanie kryteriów kontroli rozszerzyć na mentalne reprezentacje schematów, na aktywacje ${ }^{33}$ i reaktywacje, $\mathrm{z}$ drugiej zaś strony, możemy osadzić koncepcję schematu - stosując metodę hipotetycznokonstruktywną - w funkcjonalistycznej teorii użycia. O tym już wcześniej często wspominałem, na koniec odniosę się jeszcze do Wittgensteinowskiej tematyki teraz jednak uogólnionej w postaci interpretowania schematów i form życia lub też całych „światów przeżywania”. Mogłoby być tak, że w pośredniej sferze między dyscyplinami zajmującymi się znaczeniem a stanowiskami przyrodoznawczymi, opisującymi wewnętrzne aktywacje i reaktywacje schematów, ukaże się - w obliczu nowego, dynamicznego rozwoju - szczególnie płodna możliwość dalszego rozwijania tej tematyki przy pomocy koncepcji „gier schematami”.

Chcemy zatem gry schematami - zgodnie z Wittgensteinowską teorią gier językowych - określić jako osadzenie i ujęcie, dokonywane zgodnie z teorią użycia, aktywacji schematów w kontekstach uczenia się i zachowania, a również jako ujęte funkcjonalnie i dynamicznie, niejęzykowe formy reprezentacji. Kształtujemy, aktywujemy (również reaktywujemy) i stabilizujemy schematy oraz ich zastosowania, wdrażamy je - podobnie jak to sobie wyobrażał Wittgenstein w przypadku gier językowych; przy czym także wewnętrzne reprezentacje, aktywacje i reaktywacje są „splecione” z zewnętrznymi formami aktywności i życia. Przede wszystkim zaś rozumienie i każdorazowe rozpoznanie związane jest z reaktywacją odpowiednich schematów. Również tutaj użycie - tj. praktycznie wdrożone („wewnętrzne”) „zastosowanie” - jest „kryterium rozumienia”" ${ }^{4}$. Identyfikacja i poznanie wzgl. rozumienie aktywacji schematów odbywa się poprzez właściwe osadzenie $w$ ramach powtarzanych schematyzująco-interpretujących aktywności oraz poprzez ich ponowne włączenie w już uschematyzowane i społecznie ustrukturyzowane praktyczne sytuacje oraz „typowo” ujętą strukturę działań.

Koncepcja gier schematami może być tu użyteczna i da się oprzeć na bardziej ogólnym metodologicznym modelu interpretowania schematów. Może nawet możliwe byłoby mówić w tym kontekście o „grach interpretacji schematów”.

${ }^{33}$ Bazą aktywacji jest tworzenie i stabilizowanie np. zespołów neuronów (Malsburg) odpowiadające modelowi Hebbsowskich reguł bądź też modelowi elastycznego, usieciowionego, stabilizującego wzmacniania połączeń międzysynaptycznych.

${ }^{34}$ Wittgenstein, Dociekania filozoficzne, $\$ 146$. 
Zgodnie z Wittgensteinowskim modelem języka, można by ponadto mówić o „rodzinnych podobieństwach"35, jak również o grach schematami, chociaż w istocie charakterystyczne podobieństwa pomiędzy różnego typu schematami oraz ich aktywacjami są przypuszczalnie większe, niż to sobie wyobrażał Wittgenstein przy okazji gier językowych, jako że również aktywacje schematów różnych modalności zmysłowych - wizualnych czy akustycznych - przebiegają na przykład poprzez tego samego rodzaju neuronalne kanały i aktywacje o charakterze elektrofizjologicznym i biochemicznym (nawet jeśli są one specyficzne dla torowania sensorycznego). W ogólności można zatem hipotetycznie w naukowy, choć poniekąd ukryty sposób kontynuować Wittgensteinowski model w ramach filozoficznej teorii poznania na gruncie nowszych badań z obszaru neuronauk, a zarazem rozciągnąć go poza obszar badań dający się osiągnąć w publicznym języku, aby możliwości związane z mentalną reprezentacją oraz wewnętrzne aktywności móc odnieść do różnych płaszczyzn, na jakich są tworzone konstrukty interpretacyjne.

Można to osiągnąć jedynie poprzez poszerzenie Wittgensteinowskiej koncepcji gry o teorie gry schematami, ale już nie poprzez samą (terminologicznie zbyt wąską) koncepcję języka. Poza tym żywię przekonanie, że Wittgenstein nie chciał bynajmniej szerokiej i niejasno przez siebie opisanej, nieostro zdefiniowanej koncepcji gier językowych (co można było zauważyć w powyższych przykładach) odnosić jedynie do zewnętrznych zastosowań języka i kontekstów działania, lecz właściwie należałoby ją konsekwentnie rozszerzyć również na „obyczaje” i rutynowe wdrożenia wewnętrznych reprezentacji lub mentalnych reprezentacji, gdyż również tu - w podobny sposób jak w „tresowaniu” służącym opanowaniu gier językowych - zachodzi wdrażanie i przyswajanie schematów za pośrednictwem konstrukcji interpretacyjnej, konstrukcji w szerszym znaczeniu, wzgl. rekonstrukcji i (re)aktywacji. Ogólnie, koncept interpretacji schematów lub też gier schematami można określić jako owocne rozszerzenie, a zarazem jako głębsze ufundowanie - opartego na teorii funkcjonalistycznej - stanowiska Witt-gensteina w kwestii zastosowania znaków, udostępniania znaczeń, reprezentacji zewnętrznego i mentalnego rodzaju, jak i wszelkiej symbolicznej aktywności.

Jednakże owe strukturyzacje za pośrednictwem wzorów, sieci, schematów są użyteczne do tego, by tworzyć związki podobieństwa, jednorodności, przy czym

${ }^{35}$ Tamże, $\$ 67$. 
chodzi przede wszystko o to, by syngularne przeżycia, fenomeny, percepcje móc sprowadzić do bardziej ogólnych punktów widzenia, takich jak jednorodność postaci czy podobieństwo, by, że tak powiem, porządkować je z punktu widzenia podobieństwa, na przykład integrować $\mathrm{z}$ formami życia, a nawet $\mathrm{z}$ „światami przeżywania". A to porządkowanie jest ujmowaniem, osadzaniem w sieciach, relacjach, wzorach, strukturach, schematach, które ze swej strony muszą być utworzone przed lub też w trakcie swej aktywacji, o ile została ustalona ich geneza. $\mathrm{Mu}$ szą one być obecne lub stać do dyspozycji, aby można było je aktywizować. Jako wzory przerastają nawet jednostkowe fenomeny, a zatem również wszelkie pojedyncze przeżycia i stanowią most prowadzący do uogólnienia - tj. do całego każdorazowego świata przeżywanego. Tworzymy zatem konstrukty, które są mniej lub bardziej „abstrakcyjne” i umożliwiają generalizację. Owe strukturyzacje podejmuje w rzeczywistości organizm, zwłaszcza kora mózgowa, przy czym podmiot $^{36}$ „widzi”, ,interpretuje”, „wykłada”, „formuje”. Ujęcia struktur nie są dokonywane tak po prostu, lecz raczej są syntetyzowane lub właściwie selekcjonowane $\mathrm{w}$ reprezentującym ujęciu ${ }^{37}$.

Gdy się już zrozumiało, że wszystkie nasze drogi, na których zostaje nam udostępniony świat, czy będzie to droga poznania, czy działania, są zawsze „uschematyzowane”, można będzie taką metodologiczno-„,formalną” (odniesioną do

${ }^{36}$ „Podmiot”, zazwyczaj uznawany za instancję strukturyzującą, za „mentalnego aktora”, sam daje się opisać tylko jako interpretacyjny konstrukt wyższego rzędu. Podział podmiot-przedmiot sam jest uwarunkowany interpretacją (patrząc na to z teoriopoznawczej metapłaszczyzny), jest raczej abstrakcyjną „agenturą" niż „,agentem” czy aktorem.

${ }^{37}$ Nawet pre-uwagowe, przebiegające bez skupionej uwagi procesy eksploracji lub podprogowej percepcji są ukierunkowane na to, by później dostarczyć jednak uschematyzowanego ujęcia - dzięki temu bezpośrednio i natychmiast widzimy, ujmujemy przedmiot. Nie musimy seryjnie i sukcesywnie opracowywać cech i oznak (co np. musiałby „robić” typowy program komputera typu Neumannowskiego), by w wyniku dłuższego procesu móc rozpoznać „w percepcji” dany przedmiot, lecz możemy to osiągnąć natychmiast, niejako momentalnie. Nasz mózg i aparat percepcyjny mogą niewiarygodnie szybko rozpoznać wzór pracy kombinacyjnej, a jak wiadomo mają one (jeszcze) przewagę nad każdym komputerem. To momentalne rozpoznawanie wzoru możemy właściwie wyjaśnić tylko wtedy, gdy opiszemy niezwykłą równoległość przetwarzania danych w mózgu. Neuronalne sieci są włączane równolegle i nie funkcjonują w pierwszym rzędzie seryjnie. Obecnie próbuje się tego dokonać w przybliżeniu za pośrednictwem modelów, które równolegle przetwarzają dane neuronalnych sieci lub za pośrednictwem odpowiednich modelów komputerowych: a przynajmniej dąży się do tego, by stworzyć takie modele. $\mathrm{W}$ istocie koncepcja równolegle przetwarzających neuronalnych procesów wzgl. neuronalnych modeli sieciowych wydaje się być obiecująca dla przyszłych modeli komputerowych. 
form) filozofię wypracować jako szeroką perspektywę teoriopoznawczą. Dlatego mogą istnieć tylko ukształtowane w określony sposób formy strukturalne. Każdorazowe „coś” może zostać jakoś wyodrębnione, oddzielone jedynie wówczas, gdy przeciwstawimy je innym fenomenom wzgl. treściom, by stosownie do tego zostać potem oznaczone i odpowiednio ujęte. Nasz świat zostaje "ukształtowany” w swoich reprezentacjach - „najpierw (współ)ukonstytuowany”, jak mówi się w tradycyjnej filozofii - bądź reprezentatywnie ujęty lub właśnie quasi „,kkonstruowany" 38 w przedstawieniu i wyobrażeniu, a raczej „ustrukturyzowany“ w znacznej części również dzięki naszej zdolności i możliwości strukturyzowania, przedstawiania, formowania, w ten sposób, że to, co uformowane, uzyskuje swoją postać dopiero poprzez koordynację aktów formowania i procesów strukturyzacji.

Dotyczy to nie tylko poznania na bazie zmysłowej percepcji, które jest już uprzednio ustrukturyzowane i przebiega w ramach schematów - w znacznej mierze niezależnie od naszej subiektywnej woli. (Tego rodzaju przebiegi można $\mathrm{w}$ istocie poddać neurofizjologicznej kontroli). Przedstawione zależności dotyczą również pojęciowych, częściowo konwencjonalnych, a więc „kolektywnych i samowolnych" możliwości przedstawiania poprzez język. A przede wszystkim dotyczy to strukturyzującego kształtowania, jakiego dokonują działania, interwencje i projektowanie celów, na przykład poprzez uporządkowanie instrumentalne, plany itd. Innymi słowy: zewnętrzny świat - choć dotyczy to też „wewnętrznego“ świata fenomenów, którego doświadczamy - daje się ująć, o ile jego reprezentacje czy „wyobrażeniowe wersje” zostały „zrobione” przez nas, ludzi lub ukształtowane, ustrukturyzowane, „uformowane” bądź aktywowane przez znajdujące się w nas schematy interpretacyjne. Wszystko co my, jako poznające i działające istoty, możemy ująć lub przedstawić, pozostaje zależne od tego typu schematyzacji, odbywa się poprzez tego rodzaju zastosowania wzorów, poprzez rozwój, stabilizację i użycie, co oznacza: poprzez aktywację reprezentatywnych schematów bądź reprezentujących form ujmowania. Ujęcie zostaje ustabilizowane poprzez

38 „Konstruowanie” jest wyrażeniem, którego dzisiaj używają również badacze mózgu, chociaż w tym sensie naturalnie nie może być ono explicite rozumiane tak, że projektujemy świadomie, planowo, jak konstruuje inżynier czy architekt. Lecz chodzi o takie strukturyzacje, które częściowo, w niezamierzony sposób są uschematyzowane, uformowane przez osadzone biologicznie wzorce, które są zatem uwarunkowane i w znacznym stopniu przebiegają nieświadomie wzgl. podświadomie. 
odpowiadające mu reaktywacje, a zatem przez powtarzanie pierwszych aktywizacji, które dopiero umożliwiają stałość poznania i wszelkich form ujmowania ${ }^{39}$.

Człowiek jest zatem istotą zależną z konieczności nie tylko od „ujęć” posługujących się schematami lub schematyzacjami w pasywnym sensie (na przykład w bezpośredniej percepcji zmysłowej), lecz zależną również od schematycznych ujęć w aktywnym sensie - zarówno w wymiarze metodologicznym, jak i biologicznym. Człowiek to istota schematyzująca i interpretująca schematy. Można pokazać, że nawet w zmysłowym postrzeganiu zawarte są uwarunkowane biologicznie strukturyzacje $e^{40}$. Człowiek jest zatem $z$ konieczności istotą schematyzującą, która może również w świadomy sposób poznawać swoje schematy, kształtować je i w znacznej mierze uzmienniać, która używa schematów nie tylko w myśleniu, lecz również $w$ działaniu. Wszelkie myślenie, poznanie i działanie ${ }^{41}$ jest aktywną strukturyzacją, „konstytuowaniem”, które każdorazowo współobejmuje również pewien rodzaj emocjonalnego (a lepiej: emotywnego) wartościowania. Ten fakt jest dobrze znany i w międzyczasie udowodniony też neurofizjologicznie ${ }^{42}$.

${ }^{39}$ Wyrażenia „ujmowanie” używam chętnie dlatego że przedstawia ono, z jednej strony, aktywny moment w poznaniu, strukturyzowanie i nadawanie postaci, a $z$ drugiej strony odnosi się jednak nie tylko do percepcji zmysłowej, lecz ponadto do bardziej abstrakcyjnych wyobrażeń. „Ujmowanie” należy rozumieć aktywistycznie również w sensie „ujęcia”, które w nim pobrzmiewa.

${ }^{40}$ Ujawnia się to w tym, że pewne doświadczenia nie są nam dostępne, ponieważ nie mamy odpowiednich organów zmysłowych. Nie mamy na przykład organu do odbioru fal naddźwiękowych, jakie posiadają nietoperze, ani zmysłu reagującego na fale magnetyczne jak gatunki ptaków migrujących itd. Ale dysponujemy możliwościami kompensowania tych braków za pomocą technicznych instrumentów, odkryć i technologicznego rozwoju, innymi słowy, dzięki przewyższaniu zwierzęcych umiejętności.

${ }^{41}$ Myślenie, poznawanie i działanie są zawsze aktywne i fizycznie „realizowane”, są w tym samym stopniu i we wzajemnej zależności „strukturyzacjami”, dają się oddzielić wyłącznie analitycznie. W procesach aktywacji, jak i w codziennej praktyce zdolności te przechodzą nawzajem w siebie; nie pojawiają się w izolacji.

${ }^{42}$ Damasio pokazał, że nawet najbardziej abstrakcyjne myślenie, na przykład matematyka, nie może przebiegać niezależnie od emocji i afektów aktywowanych w tak zwanym systemie limbicznym, a w przypadku strachu/lęku w ciele migdałowatym itd. Reprezentacje powstające w mózgu możemy tymczasem zarejestrować za pośrednictwem nieinwazyjnej metody obrazującego „odtworzenia struktury”, jaką jest na przykład funkcjonalna spektroskopia magnetycznego rezonansu jądrowego i inne podobne metody. Można również wykazać korelatywnie udział określonych obszarów mózgu w pozornie całkowicie oderwanych od świata abstrakcyjnych procesach poznawczych. Por. António R. Damasio, Błąd Kartezjusza: emocje, rozum i ludzki mózg, wyd. II poprawione, tłum. Maciej Karpiński (Poznań: Dom Wydawniczy „Rebis”, 2011); tenże, Ich fühle, also bin ich (München: List, 2000). 
Również w przypadku reprezentacji, aktywności schematyzująco-interpretacyjnych, kształtowania i stosowania czy też stabilizacji interpretacyjnych konstruktów obowiązuje zasada, która głosi, że wszystkie te czynności można ująć jako gry schematami, kierującymi się względnie ustabilizowanymi, dającymi się (ponownie) aktywizować i podjąć regułami. Za pośrednictwem gier schematami strukturyzujemy i stabilizujemy nasze (ponowne) ujęcia - nie tylko w poznaniu, lecz również w nieodłącznym od niego działaniu.

Model, które ukazuje powiązanie całego poznania i działania z interpretacją, trzeba w perspektywie teoriopoznawczej traktować jako model oparty na hipotezach. Model ten może przedstawić wspomniane związki, ale jest on i pozostanie $\mathrm{w}$ istocie modelem metodologicznym. Podkreśla on metodologiczną konieczność zakorzenienia społecznego, ale zarazem akcentuje powiązanie interpretacji z tym, co społeczne. Nie jest to model absolut(ystycz)ny, ontologiczny, lecz jedynie stanowisko krytyczno-teoriopoznawczo-metodologiczne, które, kontynuując Sellarsa krytykę tradycyjnego „mitu tego, co bezpośrednio dane”, krytykuje mit tego, co dane z góry niezależnie od interpretacji. Można ten model pogodzić z umiarkowanym lub rudymentarnym ${ }^{43}$ realizmem ${ }^{44}$. Interpretacyjne interwencje są zawsze związane ze społecznymi (zsocjalizowanymi) normami: zarówno interpretacje schematów, jak i rzekomo prywatne opinie są dogłębnie (to znaczy konstytutywnie) związane z uspołecznieniem, ze wspólnotą interpretacyjną, z działaniami, które również można rozumieć tylko interpretacyjnie; ponadto są związane z ustanowionymi normami (na przykład reprezentacji lub uwewnętrznienia odpowiedniej aktywacji i reaktywacji schematów), z kontrolą, którą można przeprowadzić tylko w przestrzeni społecznej na podstawie zewnętrznych kryteriów, z wdrażaniem aktywacji i reaktywacji schematów - nie tylko w biologicznym sensie aktywacji schematów zespołów neuronów w jednostce, lecz również w sensie społecznego wdrażania i rozpowszechniania schematów, zachodzącego we wzajemnych relacjach między odpowiednimi, kontrolowanymi wdrożeniami schematów w reprezentujących indywiduach. Istnieją spójne oscylacje i samoorganizujące się harmonizacje wdrożeń nie tylko w jednostkach, lecz również w sferze społecznej przynajmniej w rozszerzeniu analogicznym lub w autentycznym uogólnieniu.

\footnotetext{
${ }^{43}$ Wolfgang Röd, Erfahrung und Reflexion: Theorien der Erfahrung in transzendentalphilosophischer Sicht (München: Beck, 1991).

${ }^{44}$ Por. Lenk, Erfassung der Wirklichkeit, tenże, Grasping Reality.
} 
Społeczne wdrażanie schematów można postrzegać i potencjalnie rozumieć w produktywno-kreatywnym, wzajemnym powiązaniu z odpowiadającymi im indywidualnymi aktywacjami schematów. Nie jest możliwe kierowanie się - wyłącznie i zasadniczo "privatim” bez kryteriów rejestrowania i kontroli - dokładnie określonym schematem, tzn. rzeczywistym schematem, który opiera się na powtarzalności. Jest to specyficzny wariant Wittgensteinowskiego dictum, że nie można kierować się regułą prywatnie ${ }^{45}$; nie można również wyłącznie prywatnie rozwijać języka, który dałby się kontrolować.

Zasadniczo nie można zatem aktywizować i reaktywizować schematów wyłącznie prywatnie, jeśli jesteśmy zorientowani na kontrolowalność, komunikowalność, na intersubiektywną zrozumiałość, a zatem na społeczne wdrażanie danych schematów. Interpretowania nie można rozumieć w oderwaniu od obyczajów, ponieważ jest ono zawsze powiązane ze społecznymi dyrektywami bądź ze społecznie wdrożoną kontrolą.

Interpretowanie - również w znaczeniu zastosowania schematu - oznacza zdolność do opanowania techniki: w każdym przypadku techniki interpretacji. Interpretowanie nie może być całkowicie egocentryczne i absolutnie prywatne. Zwłaszcza tworzenie płaszczyzn i warstw interpretacji, wdrażanie schematów oraz ich neuronalnych korelatów w postaci aktywacji i reaktywacji zespołów neuronów, a tym samym możliwość i zdolność do rozpoznawania i ponownego zastosowania łączą się generalnie ze społecznym usytuowaniem oraz łączą się dogłębnie ze społeczną konstytucją aktu interpretowania schematów.

Główna idea społecznej konstytucji językowych i praktycznych gier, której zaczątki pojawiły się u Wittgensteina, jest tu zatem ujęta bardziej ogólnie, w znaczeniu quasi teleologiczno-funkcjonalistycznego interpretacjonizmu schematycznego, przy czym twierdzę, że schematy wdraża się nie tylko indywidualnie, lecz ostatecznie muszą się one w praktyce oprzeć się na kontekstach społecznych, na wspólnotach interpretacyjnych, czyli na zwyczajach i obyczajach, na społecznym normalizowaniu. Zakorzenienie wzorów reprezentacji, form i sposobów interpretowania nie może być nigdy, w istocie, ufundowane absolutnie - jest to ważna i nieodzowna idea Wittgensteina - lecz zawsze ma ono charakter praktyczny

${ }^{45}$ Wittgenstein, Dociekania filozoficzne, $\$ 202$. 
i pragmatyczny. Działamy i interpretujemy praktycznie, pozostając zawsze w ramach społecznej i kulturowej wspólnoty, wspólnoty interpretacyjnej i wspólnoty języka, ostatecznie musimy się zawsze do nich odnosić i nie możemy od nich abstrahować. Nie możemy ustalić absolutnego fundamentu niezależnego od tych społecznych unormowań. Nie możemy również postulować absolutnych faktów jako racji uzasadniających nasze obyczajowe ujmowanie pojęć, kierowanie się regułami lub wewnętrzne zróżnicowania procesów mentalnych; ponieważ fakty same $w$ sobie nie dają się po prostu jako takie opisać, można je tylko ujmować i uchwytywać w świetle odpowiadających im interpretacji i odnośnych orientacji, definicji celów, form życia, perspektyw, które są bezpośrednio uwikłane w nasze „bycie-w-świecie”, a zatem również w nasz każdorazowy świat przeżywania ${ }^{46}$.

Idea całości odgrywała naturalnie pewną rolę już u Kanta, w znaczeniu aktywnego formowania poznania i rezultatów procesu poznawczego poprzez określone formy intelektu - wzgl. poprzez wyższe, abstrakcyjne, niezwiązane z doświadczeniem wglądy dokonywane przez rozum. Ten postulat Kanta utrzymał się właściwie do dzisiaj. Jednakże z pewnym odstępstwem: Kant zakładał, że formy intelektu, za pośrednictwem których człowiek przedstawia, ujmuje swoje poznanie, na przykład w ramach doświadczenia, są zawsze takie same dla wszystkich istot rozumnych. Te formy, że tak powiem, są utrwalone w istocie rozumu, jak sądził Kant. Tego poglądu nie można już jednak po prostu przyjąć, gdyż obecnie dysponujemy o wiele większą możliwością wariacji. Podchodzimy do tej kwestii o wiele „bardziej liberalnie“, niż to wyobrażał sobie Kant.

Jednakże należy stwierdzić, że tym, co zachowało aktualność w filozofii Kanta, jest teza o tak zwanym „subiektywnym”, związanym z podmiotem charakterem form poznania. Ale to nie oznacza, że każda tego typu forma jest dowolna w znaczeniu „subiektywna”, tak jak rozumiemy to określenie w mowie potocznej; wyrażenie „subiektywny” wskazuje na to, że owe formy są „dostarczane”, wpajane poznającemu podmiotowi, że są w nim w jakiś sposób obecne czy umocowane.

${ }^{46} \mathrm{~W}$ najlepszym razie możemy analitycznie odróżnić interpretacje faktów - jak przedstawiono powyżej - jako rodzaj „bezpośrednich” impregnacji (przeprowadzonych za pośrednictwem tak zwanych „Czynników światowych”) od zwykłych produktów interpretacji, na przykład wtórnego wytwarzania społecznych bytów - i tak należy robić. Ale to są wszystko - mówiąc językiem czysto metodologicznym - wewnątrzinterpretacyjne rozróżnienia, które nie mogą umniejszyć niczego ani w metodologicznej konstytucji i umiejscowieniu schematycznych interpretacji, ani w interpretacyjnej praktyce, która odbywa się w danej formie życia i kulturowej oraz społecznej wspólnocie interpretacyjnej. 
Formy te są zatem „podmiotowe”, ale nie są dowolne. Może tak być, a często tak właśnie jest, na przykład w bezpośredniej percepcji, że niemal przymusowo przeżywamy obiektywność postrzegania - na przykład przy normalnej widoczności dostrzegamy różnicę między tonami jasnymi i ciemnymi oraz odpowiadające im kontrasty. Nie możemy inaczej postrzegać niż w sposób poznawczy. W tym tkwi coś z konieczności obiektywnej (przedmiotowej) i intersubiektywnej. Musimy zatem, na przykład, w zewnętrznym i bezpośrednim postrzeganiu zmysłowym uznawać w określonym zmyśle ( $\mathrm{w}$ pewnych granicach) obiektywność „ujęć”, którą można również rozumieć jako „intersubiektywność”. To ostatnie oznacza, że inni ludzie mogą w ten sam sposób przeprowadzić doświadczenie bądź też „ujęcie”, że można je reprodukować, powtarzać, ponieważ - musimy tak myśleć u podłoża tego wszystkiego tkwi quasi-realna niezmienność.

Najważniejsze, w gruncie rzeczy, jest to, że mimo iż strukturyzacja zależy od podmiotu, to można za jej pośrednictwem uznać istnienie swego rodzaju obiektywności egzystencji, na przykład zewnętrznych rzeczy lub zewnętrznego świata ${ }^{47}$. Tę obiektywność można też w pewnym sensie ponownie zbadać za pomocą strukturyzacji teoriopoznawczego rodzaju. Interpretacjonizm czy interpretacjonizm schematów należy zatem ujmować na różnych stopniach poznania. To stanowisko ma charakter modelowy; dlatego mówię o metodologicznym interpretacjonizmie schematów i rozróżniam rozmaite stopnie schematyzacji ${ }^{48}$.

Stanowisko to można jednak ująć w całkiem Kantowskim sensie jako analizę koniecznych warunków poznania (i działania!), jako rodzaj umiarkowanego, bardziej liberalnego stanowiska, które dopuszcza wariacje ${ }^{49}$.

${ }^{47} \mathrm{Na}$ przykład przeżywamy pewnego rodzaju opór w trakcie działania. Wielu filozofów wykorzystywało go jako kryterium „rzeczywistości zewnętrznego świata”. To naturalnie nie jest pozbawione sensu; ponieważ, jeśli uderzymy głową o ścianę i nabijemy sobie guza, możemy w większości przypadków (pomijając przenośne znaczenie tej sytuacji) uznać ten fakt trywialnie za „świadectwo” istnienia świata niezależnego od podmiotu.

${ }^{48}$ Por. załącznik.

49 „Transcendentalne” jest dla Kanta stanowisko, które dotyczy warunków - w istocie warunków koniecznych, ale również wystarczających - możliwości poznania. Jakie warunki musi spełnić poznanie, by było wiarygodne pod względem naukowym, obiektywnym? Pytanie to odnosi się naturalnie również do potocznego poznania. Kantowska filozofia jest zasadniczo teorią poznania potocznego, a nie, jak sądził Kant, teorią nauki lub filozofią nauki odniesioną do fizyki Newtona. Wprawdzie miał on to na myśli, ale nie do końca słusznie. Moglibyśmy również mówić tutaj o „quasi-transcendentalnym” interpretacjo- 
Chciałbym jednak ograniczyć się do tego, by mówić tylko o stanowisku metodologicznym - i z tego powodu nazywam je metodologicznym interpretacjonizmem schematów. Jako taki byłby on skromniejszą wersją transcendentalizmu à la Kant. Choć ów metodologiczny interpretacjonizm schematów w pewnym sensie obejmuje także Kantowską teorię poznania - lub jej część - to jednak rozpatruje poznanie i działanie tylko w kontekście metodologicznym, to znaczy analizuje sposób, w jaki akty poznawcze, rozumiane jako procesy wzajemnie powiązane, zostają dopiero ukształtowane. Dopiero wtórnie do tak pojętego interpretacjonizmu dochodzi teoria poznania i ewentualnie to, co transcendentalne czy też quasi-transcendentalne - czyli wtedy, gdy element metodologiczny daje się powiązać z empirycznym realizmem w Kantowskim, a nawet ogólnym znaczeniu. $\mathrm{W}$ istocie, taki realizm ${ }^{50}$ opierałby się na tezie, że wszelkie reprezentacje i sposoby ujmowania, wszelkie przedmioty, ba, wszelkie (również abstrakcyjne) obiekty ujmowania - a więc nie tylko zewnętrzne przedmioty, lecz również te "przedmioty“, które tylko „domniemujemy” - podlegają podmiotowym, perspektywicznym, uzależnionym od odpowiedniego położenia podmiotu ograniczeniom i warunkom poznania, podlegają więc określonym prawidłowościom. Przy tym jednak, jak się powiada, możemy bez wątpienia przyjąć obiektywność przedstawienia o tyle, o ile możliwa jest intersubiektywność i o tyle, o ile możemy również przyjąć, że odpowiednim doświadczeniom, na przykład zewnętrznemu postrzeganiu odpowiada „ukryty w tle” byt. (To założenie obowiązuje przynajmniej z punktu widzenia określonej perspektywy metodologicznej).

W naszym podejściu chodzi przede wszystkim o pragmatyczny dostęp do teorii poznania i fundamentalny punkt wyjścia dla filozofii zorientowanej na metodyczne badanie, $\mathrm{w}$ takim stopniu, $\mathrm{w}$ jakim wychodzi ona od poznania i ludzkiego działania, od formujących, kształtujących, schematyzujących, interpretujących aktywności, które są powiązane z myśleniem, poznaniem i działaniem. Cho-

nizmie schematów w zmodyfikowanym znaczeniu, w którym to wyrażenie używane jest w umiarkowanie transcendentalny sposób, a zatem nie w Kantowskim sensie, że ów interpretacjonizm podaje jedynie możliwe warunki, a zatem „formy”, którym musi sprostać poznanie (aby w ogóle było możliwe obiektywne lub przedmiotowe poznanie), lecz w tym sensie, że zostają podane podstawy dla strukturyzacji, „schematyzacji” itd. (Te formy mogłyby być całkiem odmienne u innych poznających istot rozumowych, na co Kant nie chce się zgodzić).

${ }^{50}$ Por. Lenk, Erfassung der Wirklichkeit. 
dzi zatem o pragmatyczny konstytucjonalizm lub schematyczny interpretacjonizm ujęć, który zawiera dwa warianty, z jednej strony, metodologiczny interpretacjonizm schematów, a z drugiej, właśnie „liberalny” transcendentalny lub quasi transcendentalny wariant - quasi-transcendentalnego interpretacjonizmu schematów. Obydwa warianty można pogodzić z ujęciem z potocznego poznania i potocznymi strukturyzacjami działania oraz powiązać $\mathrm{z}$ teorią poznania w znaczeniu krytycznego realizmu, dzięki czemu (można) ująć wyjaśnienia, teorię poznania, etyczne schematyzacje również w odniesieniu do naukowego poznania lub do relacji z „zewnętrzną rzeczywistością”51.

$\mathrm{Z}$ drugiej strony, również samo powiązanie jest postrzegane i dane w pewnej antropologicznej perspektywie: człowiek zostaje przy tym ujęty jako istota interpretująca schematy w tym określonym sensie, że posiada zdolność do używania swoich schematyzacji i strukturyzacji przedmiotu w analizie danego ujęcia lub w teorii wyższego rzędu. Z tego powodu nie twierdzę tylko, że człowiek - jak trafnie ujął to Nietzsche - jest „istotą interpretującą”, która zawsze musi interpretować i jedynie dzięki interpretowaniu może działać i poznawać, lecz ponadto utrzymuję, że człowiek jest istotą metainterpretującą ${ }^{52}$, istotą, która własne interpretacje oraz rezultaty wszelkich strukturyzacji i schematyzacji poznania i działania może i musi uczynić przedmiotem poznania lub ujęcia wyższego rzędu ${ }^{53}$.

${ }^{51}$ Naturalnie również założenie wyższego rzędu (jednej) „zewnętrznej rzeczywistości” zależy z czysto metodologicznej perspektywy wyższego rzędu - od interpretacji. Zasada ta obowiązuje bez konieczności przyjmowania stanowiska ontologicznego lub teoriopoznawczego (totalnego) idealizmu. Wiąże się z nią tylko metodologiczne, odpowiednio osłabione ujęcie quasi Kantowskiego „transcendentalnego idealizmu", niejako quasi-transcendentalizmu.

${ }^{52}$ Por. Hans Lenk, „Das metainterpretierende Wesen”, Allgemeine Zeitschrift für Philosophie 20, Heft 1(1995): 39-47.

${ }^{53}$ Tym właśnie wydają się wyróżniać ludzie, ponieważ zwierzęta nie są zdolne do tego rodzaju zachowań poznawczych. Co prawda szympansy używają narzędzi, potrafią wyuczyć się elementarnego języka, nie tyle jednak werbalnego, lecz np. języka gesturalnego, jakim posługują się osoby głuchonieme lub języka utworzonego na wzór gry w scrabble z leksygramów na komputerze. Z całą pewnością potrafią używać symboli, dlatego w pewnym sensie również one są „symbolicznymi istotami”. Jak wiadomo, Cassirer próbował definiować człowieka jako „istotę symboliczną, ale próba ta jest niewystarczająca (nawet jeśli uwzględnimy to, że miał on na myśli również zdolność do symbolizacji wyższego rzędu). Omawiana tu problematyka staje się bardziej klarowna terminologicznie i bardziej systematyczna dopiero wtedy, gdy mówimy o „metasymbolicznej istocie” lub „istocie tworzącej metapoziomy”: a więc o istocie, która swoje własne symbole może uczynić przedmiotem (obiektem) analizy, która może np. analizować symbole językowe na wyższym poziomie abstrakcji, uprawiając przykładowo gramatykę lub „głęboką gramatykę" (à la Wittgenstein lub Chomsky). 
Nieodzowne jest przy tym, by człowiek posiadał zdolność do wznoszenia się na wyższe stopnie abstrakcji, symbolizacji, tworzenia znaków i agregowania złożonych informacji w formacjach wyższego rzędu. Człowiek jest związany nie tylko z jakąś warstwą reprezentacji, lecz może tworzyć reprezentacje wyższego rzędu. Dzięki temu uzyskuje pewnego rodzaju zdolność do wznoszenia się na szczeblach abstrakcji, dzięki czemu nabywa możliwości kreatywnych ${ }^{54}$, dzięki czemu zyskuje pewnego typu „wolność” w interpretowaniu jednego i tego samego podstawowego fenomenu, zależnie na przykład od teoretycznych i pojęciowych konstrukcji lub zastosowanych teoretycznych formacji, konceptów, planów działania itd. Wreszcie człowiek sam może tę metodę ponownie przebadać i przeanalizować, choćby $\mathrm{w}$ metodologii postępowania naukowego lub w teorii poznania. Odnosi się to, rzecz jasna, do całościowej interpretacji jego bądź naszych „światów przeżywania” lub „form życia”.

Na koniec możemy rozszerzyć słynne twierdzenie Kartezjusza w taką oto formułę: działam, reaguję, zachowuję się, odczuwam („doznaję“) - jestem pobudzany lub pobudzam się - mniej lub bardziej świadomie postrzegam, tworzę reprezentacje, konstytuuję, interpretuję w częściowo idiosynkratycznych formach życia, w „moim” świecie przeżywanym: to wszystko reprezentuje pragmatycznie rozszerzone Kartezjańskie „cogito”: Interpretando cogito, ago ${ }^{55}$, cooperaor, ergo mentaliter sum.

\section{Załącznik}

Poza tym możemy wskazać na omówiony wcześniej przeze mnie przegląd stopni interpretacji (schematu) ${ }^{56}$. (H.L. 1993, 56; 2004, 75f. u. a):

${ }^{54}$ Por. Lenk, Denken und Handlungsbindung, tenże, Bewusstsein, Kreativität und Leistung (Darmstadt: WBG Primus, 2007).

${ }^{55}$ Dla ścisłości należałoby jeszcze dodać interaktywno-społeczne komponenty: interago, cooperatione facio, intervenio. Por. Hans Lenk, Einführung in die Erkenntnistheorie: Interpretation - Interaktion - Intervention (München: UTB, 1998).

${ }^{56}$ Por. Lenk, Interpretationskonstrukte, 56; tenże, Bewusstsein als Schemainterpretation, 75 i n. 
(Płaszczyzny) stopnie interpretacji:

$\mathrm{IS}_{1}$ nie podlegająca praktycznym zmianom, produktywna

pierwotna interpretacja

(prymarna konstytucja, wzg. schematyzacja)

$\mathrm{IS}_{2}$ tworząca nawyki i jednorodność

wzorcowa interpretacja

(habitualna kategoryzacja

form i schematów +

przedjęzykowe tworzenie pojęć)

$\mathrm{IS}_{3}$ społecznie ufundowane, przekazywane w kulturze, przejęte,

konwencjonalne tworzenie pojęć

$\mathrm{IS}_{3 \mathrm{a}}$ przedjęzykowo unormowane tworzenie pojęć i

interpretacja dokonywna za pośrednictwem społecznych i kulturowych unormowań

$\mathrm{IS}_{3 \mathrm{~b}}$ odsyłające do reprezentacji, językowo unormowane

tworzenie pojęc $c^{57}$

$\mathrm{IS}_{4}$ stosowana, przyswajająca świadomie ufomowana

interpretacja przyporządkowania

(klasyfikacja, subsumcja,

opis,

tworzenie i przyporządkowanie rodzajów;

celowe tworzenie pojęć)

IS $_{5}$ wyjaśniająca, „rozumiejąca” (w ścisłym słowa tego znaczeniu) uzasadniająca (teoretyczna) ugruntowujacca interpretacja,

${ }^{57}$ Wyodrębniony tu stopień $\mathrm{IS}_{3}$ stanowi modyfikację podziału przedstawionego we wcześniejszej pracy. Por. Lenk, Interpretationskonstrukte. 


\section{interpretacja o charakterze uzasadnienia}

$\mathrm{IS}_{6}$ teoriopoznawcza (metodologiczna)

metainterpretacja

metody konstruktów interpretacyjnych

Na pierwszym stopniu IS ${ }_{1}$, zwanym „stopniem podstawowym”, występuje tworzenie pierwotnego wzorca lub prymarnej interpretacji, prymarnej schematyzacji, która $\mathrm{w}$ istocie jest nam dana w postaci niezmiennej i niezmienialnej. Ta schematyzacja jest uwarunkowana operacjami poznawczymi lub ustalona biologiczno-genetycznie. Przykładowo, jeżeli w ogóle możemy coś zobaczyć, rozróżniać „jasny” i „ciemny” ton i gdy koncentrujemy się na kontraście jasne/ciemne, to musimy tak robić, gdyż jest to już ustalone na poziomie biologicznym. Nie możemy tego samowolnie zmienić nawet wtedy, gdy użyjemy urządzeń technicznych itd. (Ale nawet wtedy, gdy używamy takich urządzeń lub odczytujemy z nich dane, to i tak pojawiają się kontrasty uwarunkowane fizjologią percepcji.) Istnieją zatem schematy percepcji prymarnej - i naturalnie również schematy odpowiadających im prymarno-schematycznych sposobów zachowania się i reakcji (nie może tu nawet być mowy o „działaniach” w ścisłym słowa tego znaczeniu)

Do tego stopnia można zaliczyć wszystkie reakcje odruchowe, odruchy, ale nie możemy ich zmienić, ponieważ są one, że tak powiem, biologicznie trwale „okablowane” i w tym sensie na poziomie praktyki życiowej nie podlegają żadnym zmianom. Istnieje nawet płaszczyzna operacjonalnie koniecznych, nie tylko biologicznych, organicznie niezmiennych, genetyczne utrwalonych, lecz również utrwalonych praktycznie wzorców, które można określić jako stopień schematyzacji prymarnych. Na wyższych stopniach występuje większa zmienność; możliwość zmiany schematów staje się tu coraz większa. Ponad stopniem $\mathrm{IS}_{1}$ alternatywy interpretacyjne są nieco bardziej zmienne i w coraz większym stopniu dają się ustalać świadomie.

$\mathrm{Na}$ drugim stopniu $\mathrm{IS}_{2}$ znajdujemy na przykład większość ujęć odwołujących się do podobieństwa, jednakowości, jednorodności, a zatem wzorcowych interpretacji, które na przykład odkrywamy przy okazji postrzegania barw, form itd., które są aktywizowane i porządkowane (najczęściej nieświadomie) w percepcji ${ }^{58}$

\footnotetext{
${ }^{58}$ Nawet wówczas, gdy występują tego rodzaju „impregnacje”, które zmuszają nas do odgraniczania i wyodrębniania napływających z zewnętrznego świata konstelacji, konfiguracji bodźców.
} 
- według pewnych perspektyw podobieństwa, równokształtności, (strukturalnej) jednorodności itd. Przede wszystkim dzieje się to nie tyle za pośrednictwem języka, lecz jest kształtowane prewerbalnie ${ }^{59}$.

Możemy tu poza tym włączyć rozróżnienie zachodzące w percepcji, które uwzględnia pewne wspierające działanie momenty lub cechy wyodrębnione z powodu ich wyrazistości i podobieństwa, uchwytywane przed jakimkolwiek językowym ujęciem. W tym sensie przedjęzykowe rozróżnianie ${ }^{60}$ jest kluczowe. Ma ono charakter habitualny. Przy tym nie wszystko jest tu genetycznie zaprogramowane, chociaż genetyczne wyposażenie i oprogramowanie stanowią podłoże dla dokonywanych zmian.

$\mathrm{Na}$ trzecim stopniu $\mathrm{IS}_{3}$ mamy - społecznie zakorzenione, kulturowo ukształtowane i przekazywane tradycją, uformowane „w" $\mathrm{i}$,za pośrednictwem” form życia lub każdorazowego świata przeżywanego - unormowane wzorce, które są "postrzegane" w podwójnym znaczeniu: z jednej strony, jako wzorce, które zostały lub zostaną preformowane i „pre-unormowane” przez społeczną wspólnotę i które uwidaczniają się również w określonych konstelacjach symboli, a nawet w zewnętrznych znakach, i jako takie są właśnie „postrzegane” - w tym sensie, że podążamy za tego rodzaju normami, że określają one nasze działania i w schematyzujący sposób je reprezentują. To, co stanowi rezultat konwencjonalnego ustanowienia, zostaje podniesione do rangi normy ${ }^{61}$, jest i staje się częścią świata przeżywanego, jako takie podlega stylizacji, jest wyuczone, uwewnętrznione i musi być

${ }^{59} \mathrm{~W}$ psychologii próbowano badać również niejęzykowe, tzn. „pojęciowe” postrzeganie i klasyfikowanie lub myślenie (prewerbalne pojęcia, prewerbalne „rozróżnianie”), ale nie zaliczyłbym wspomnianych w tekście, wzorcowych interpretacji do tej klasy aktywności, ponieważ na omawianym stopniu chodzi raczej o zachowania rutynowe, o poznanie oparte na nawykach.

${ }^{60}$ Zamiast tego na pierwszym planie pojawia się nawykowa konfrontacja z określonymi sytuacjami lub bodźcami czy cechami - a zatem reakcje, które są stopniowo doskonalone i stanowią rezonans, również w sensie wspomnianego, będącego reakcją na sytuację stabilizowania, w którym uczestniczą zespoły neuronów poddane spójnej oscylacji. To wszystko miałem tutaj na myśli, choć nie wyraziłem tego wprost. Wzorcowe podobieństwo oraz wzorcowa interpretacja są w tym sensie silniej wyuczone i bazują na utrwalonych genetycznie predyspozycjach.

${ }^{61}$ Normowanie konwencjonalnych wzorców zachowania i myślenia następuje za pośrednictwem społecznej praktyki ćwiczenia, tj. kontrolowanej i sankcjonowanej „tresury” czy „dyscyplinowania” (Wittgenstein, Dociekania filozoficzne, $\$ 5$ i n.). Do tego niezbędne są oczywiście określone sytuacje, w których zdobywamy odpowiednie doświadczenie, w których uczymy się konkretnych praktyk. Można to sobie uzmysłowić zwłaszcza na przykładzie przyswajania określonych pojęć. Bernd M. Scherer, Prolegomena zu einer einheitlichen Zeichentheorie. Ch. S. Peirce' Einbettung der Semiotik in die Pragmatik 
przestrzegane. Musimy zatem na tym stopniu uporządkować to, co zostało konwencjonalnie wdrożone w kulturze i społeczeństwie za pośrednictwem uzgodnienia oraz rutynizacji. Zastosowanie schematów musi być tu każdorazowo „wdrożone" w praktyce interpretowania, mniej lub bardziej świadomego kierowania się regułami, używania wzorów itd. Jest to społeczny proces uczenia się i nauczania, odbywający się na licznych stopniach interpretacji i wykraczający poza niektóre z nich, zwłaszcza gdy jest on już językowo reprezentowany i ustrukturyzowany

$\mathrm{Na}$ trzecim stopniu społeczno-konwencjonalne twory pojęciowe $\mathrm{w}$ przestrzeni przedjęzykowej należy odróżnić od językowo-konwencjonalnych, normatywnych tworów pojęciowych, które (werbalnie) reprezentują w ścisłym tego słowa znaczeniu. Istotny jest fakt, że szczególną rolę odgrywają tu formy językowo wyuczone, przy czym "język” może oznaczać zarówno język w szerokim tego słowa znaczeniu, jak i języki sztuczne, różnego rodzaju twory znakowe, gesty, symbole, zawierające jakieś przedstawienia lub wskazówki wzgl. rozkazy itd., specjalne notacje, systemy zapisu, matematyczne formuły itd. Wszystko to należy do konwencjonalnego tworzenia pojęć w najszerszym słowa tego znaczeniu i tym bardziej odnosi się do werbalnego języka w węższym tego słowa znaczeniu.

W ramach analizy, należy odróżnić obie płaszczyzny IS $_{3 a}$ i IS $_{3 b}$, jednakże w obu występuje konwencjonalizacja i normowanie. Dlatego jest w pełni uzasadnione umieszczenie obu podrodzajów konwencjonalnych interpretacji (schematów) na jednym stopniu.

Czwarty stopień $\mathrm{IS}_{4}$ byłby tym stopniem, na którym świadomie porządkujemy rozległe struktury i pojęcia, a zatem świadomie reprezentujemy takie struktury i schematy, które już zostały lub zostaną opisane językowo, szeregujemy w obszerne klasy, kategorie, pojęcia rodzajowe i gatunkowe. Tutaj możemy ulokować wszelkiego rodzaju zamierzone zaszeregowania, twory strukturalne i poję-

\footnotetext{
(Tübingen: Stauffenburg, 1984) - zbadał na bazie Peirce'owskiej teorii znaku kolejne etapy w procesie tworzenia takich pojęciowych konstelacji, przy czym wyróżnił rozmaite sytuacje początkowe, na przykład sytuacje nauczania i uczenia się pierwszego i drugiego stopnia. Wzorzec pojęciowy wdrażamy do użycia dzięki aktywacji wzorca działania. Gdy już go przyswoimy, możemy go dowolnie przy- lub odwołać, wskazując po prostu znak lub obraz. Scherer ilustruje to na przykładzie pływania: w pływaniu dostrzegamy działanie, które można zaklasyfikować, ale później gdy już wyuczymy się tego sposobu symbolicznego reprezentowania (czynności) i opanujemy (językową) reprezentację, wówczas będziemy mogli wywołać wyobrażenie jedynie za pośrednictwem słowa.
} 
ciowe, używając środków językowych lub językopodobnych. Mówię o szeregujących interpretacjach, moglibyśmy również mówić o kategorialnych lub kategoryzujących wzgl. klasyfikacyjnych interpretacjach w ścisłym tego słowa znaczeniu. Wszelka klasyfikacja, opis, subsumcja, wszelkie ulokowanie w siatce rodzajów i gatunków, zamierzone formowanie pojęć w ścisłym znaczeniu odgrywają tutaj rolę decydującą.

Następny stopień $\mathrm{IS}_{5}$, obejmuje teoretyczne wykładnie, które uzasadniają i legitymizują, tj. argumentatywne interpretacje lub legitymizujące interpretacje w najszerszym tego słowa znaczeniu; przy czym wychodzi się tu poza zwykłe zaszeregowanie. Na tym poziomie interpretacji poszukuje się uzasadnień i legitymizacji dla sposobów reagowania, zachowania, działania oraz explicite - używając argumentów - wytwarza się wzgl. ujawnia kontekst wyjaśniająco-teoretyczny lub oceniający. Argumentatywne konstruowanie kontekstu jest istotną oznaką owej legitymizującej interpretacji. „Legitymizowanie” nie odnosi się przy tym bynajmniej jedynie do argumentacji lub uzasadniania naukowego czy naukopodobnego, lecz również do konstruowania kontekstu w życiu codziennym ${ }^{62}$. Mam tu na myśli nie tylko uzasadnienia lub strukturyzacje teoretyczne czy naukowe, lecz też codzienne. Odnosi się to nie tylko do uzasadnień, za pomocą których „wyjaśniamy” nasze własne działania czy działania innych osób, lecz również do planowania działań, ustalania celów, normowania, szeregowania pod reguły, nakazy, zakazy itd. Wszystko to można zaszeregować pod etykietę interpretacji legitymizującej.

Jest jednak jeszcze szósty i ostatni stopień $\mathrm{IS}_{6}$. Jest to stopień metainterpretacji, tj. stopień teoretyczno-poznawczy lub - jak kto woli - stopień metodologiczny, na którym podejmujemy nasze postępowanie i metodę interpretacyjną lub

${ }^{62}$ Psycholodzy mówią o „naiwnych teoriach życia codziennego”, za pośrednictwem których przedstawiamy i rozumiemy relacje zachodzące w naszym świecie. Również w zwykłym życiu jesteśmy, że tak powiem, teoretykami i twórcami hipotez. Używamy ogólnych pojęć, porządkujemy przedmioty w określone klasy, rodzaje i gatunki; wyciągamy wnioski dotyczące pewnych prawidłowości, przeprowadzamy wnioskowania kauzalne lub motywacyjne itd. Również na co dzień mniej lub bardziej „naiwnie" teoretyzujemy; używamy naszych utrwalonych ogólnych reguł. W życiu codziennym postępujemy zatem podobnie jak w nauce, jesteśmy „małymi badaczami”. Jesteśmy niemal uzależnieni od tego: nasze życie nie polega przecież na chaotycznym, partykularnie-przypadkowym reagowaniu. Potrzebujemy szeroko zakrojonych teorii i musimy je tworzyć, ponadto musimy być w stanie uzasadniać, tworzyć systematyczne powiązania, przyjmować założenia, antycypować, sprawdzać, i w tym właśnie sensie stosować uzasadniające interpretacje na najrozmaitszych płaszczyznach 
ustalamy rezultaty interpretacji jako przedmioty analizy i czynimy je przedmiotem (meta-)interpretacji wyższego rzędu.

Wspominałem już, że konstrukcje interpretacji (schematów) (a także ich interpretanty lub schematyzanty) - patrząc na to z perspektywy metodologicznej są konstruktami. O postępowaniu i konstrukcie interpretacyjnym na coraz wyższej (meta)płaszczyźnie mówimy wtedy, gdy analizujemy ją jako teoretycy poznania lub metodolodzy. Tworzymy przy tym i używamy metateorii. Gdy mówimy o językowych formach, potrzebujemy języka wyższego stopnia, tak zwanego metajęzyka, w którym mówi się o językowych wyrażeniach niższego rzędu. Językowe wyrażenia niższego rzędu są przedmiotami metajęzyka. W przypadku analizy interpretacyjnej należałoby mówić o językowym przedstawieniu, na przykład o wyrażeniach interpretacyjnych itd., czyli o tworzeniu stopnia metajęzykowego. W przypadku teoretycznej koncepcji dotyczącej procesu interpretowania należałoby raczej mówić o meta teorii interpretacji, a raczej o tworzeniu metastopni typu teoretycznego lub metajęzykowego, gdy przechodzimy do bardziej abstrakcyjnych, wyższych stopni opisu schematyzacji. W istocie chodzi tu również o konstrukcje z zakresu teorii modeli, rzecz jasna uporządkowane na coraz wyższych płaszczyznach, które strukturalnie podlegają tym samym warunkom co postępowanie interpretacyjne niższych stopni ${ }^{63}$.

Zjęzyka niemieckiego przełożył Rafał Michalski

${ }^{63}$ Również wyższe stopnie wykazują wspomniane cechy interpretacyjnego uformowania wszelkich aktów ujmowania. W ten sposób możemy zatem zastosować metodę konstruktów interpretacyjnych - a ściślej - metodologię wytworów konstruktów interpretacyjnych - do niej samej. Konstrukty interpretacyjne możemy ująć i zastosować jako przykład instancjalizacji ich własnej metody. Nie oznacza to sprzeczności i błędnego koła, gdyż chodzi tu o odnoszącą się do samej siebie koncepcję, która prowadzi do tego, że możemy się wznosić na coraz wyższe poziomy interpretacji i do coraz bardziej abstrakcyjnych koncepcji, ale równocześnie możemy bardziej starannie rozróżniać relacje między interpretacjami różnego stopnia. Jeśli na przykład same konstrukty interpretacyjne potraktujemy jako przykład teoriopoznawczej metody analizy interpretacyjnej, to będziemy mogli powiedzieć, że metoda ta da się modelowo zastosować - akumulując warstwy (interpretacji) - do samej siebie lub stwierdzić, że te konstrukty dotyczące konstruktów kierują się „tym samym” (identycznym strukturalnie) wzorem i nakładają się na siebie zgodnie ze specyficznymi warstwami. 
Pobrane z czasopisma http://kulturaiwartosci.journals.umes.pl

\section{Bibliografia}

Damasio, António R. Błąd Kartezjusza: emocje, rozum i ludzki mózg. Tłum. Maciej Karpiński. Wyd. II poprawione. Poznań: Dom Wydawniczy „Rebis“, 2011.

Damasio, António R. Ich fühle, also bin ich. München: List, 2000.

Hubel, David H. Auge und Gehirn: Nneurobiologie des Sehens. Heidelberg: Spektrum, 1989.

Kelly George H. The Psychology of Personal Constructs, Bd. I-II. New York: Norton, 1955.

Kripke, Saul A. Wittgenstein über Regeln und Privatsprache. Frankfurt/Main: Suhrkamp, 1987.

Laucken, Uwe. Naive Verhaltenstheorie. Stuttgart: Klett Verlag, 1974.

Lenk, Hans. „Zu einem methodologischen Interpretationskonstruktionismus“. Zeitschrift für allgemeine Wissenschaftstheorie 22, Heft 2 (1991): 283-302.

Lenk, Hans. Interpretationskonstrukte. Zur Kritik der interpretatorischen Vernunft. Frankfurt am Main: Suhrkamp, 1993.

Lenk, Hans. Philosophie und Interpretation. Frankfurt/Main: Suhrkamp, 1993.

Lenk, Hans. Schemaspiele. Frankfurt/Main: Suhrkamp, 1995.

Lenk, Hans. Interpretation und Realität. Frankfurt/Main: Suhrkamp, 1995.

Lenk, Hans. „Das metainterpretierende Wesen”. Allgemeine Zeitschrift für Philosophie 20, Heft 1(1995): 39-47.

Lenk, Hans. Einführung in die Erkenntnistheorie: Interpretation - Interaktion - Intervention. München: UTB, 1998.

Lenk, Hans. Erfassung der Wirklichkeit. Würzburg: Königshausen \& Neumann, 2000.

Lenk, Hans. Kreative Aufstiege. Zur Philosophie und Psychologie der Kreativität. Frankfurt/Main: Suhrkamp, 2000.

Lenk, Hans. Das Denken und sein Gehalt. Oldenbourg: München, 2001.

Lenk, Hans. Denken und Handlungsbindung. Freiburg: Karl Alber, 2001.

Lenk, Hans. Kleine Philosophie des Gehirns. Darmstadt: WBG Primus, 2001.

Lenk, Hans. Grasping Reality. Singapore: World Scientific, 2003.

Lenk, Hans. Bewusstsein als Schemainterpretation. Paderborn: Mentis, 2004.

Lenk, Hans. Bewusstsein, Kreativität und Leistung. Darmstadt: WBG Primus, 2007.

Lenk, Hans. Skarica M. Wittgenstein und die schema-pragmatische Wende. Berlin: LIT Verlag, 2009.

Malsburg, Christoph von der. „Am I Thinking Assemblies?”. W: Brain Theory: Proceedings of the First Trieste Meeting on Brain Theory, red. Günther Palm, Ad Aertsen, 161-176. Berlin-Heidelberg-New York: Springer Verlag, 1986.

Mind as Motion: Explorations in the Dynamics of Cognition, red. Rober F. Port, Timothy van Gelder. Cambridge: MIT Press, 1995.

Neisser, Ulric. Kognition und Wirklichkeit. Stuttgart: Klett-Cotta, 1979.

Neisser, Ulric. Kognitive Psychologie. Stuttgart: Klett-Cotta, 1974.

Posner, Michael I., Raichle Marcus E. Bilder des Geistes: Hirnforscher auf den Spuren des Denkens. Heidelberg: Spektrum Akademischer Verlag, 1996. 
Röd, Wolfgang. Erfahrung und Reflexion: Theorien der Erfahrung in transzendentalphilosophischer Sicht. München: Beck, 1991.

Rumelhart David E. Schemata. The Building Blocks of Cognition, CHIP Report 79 (San Diego: Center for Human Information Processing, University of California, 1978). Opublikowane także w: Theoretical Issues in Reading Comprehension, red. Rand J. Spiro, Bertram C. Bruce, William F. Brewer. Hillsdale, 33-57. NJ: Lawrence Erlbaum, 1980.

Scherer, Bernd M. Prolegomena zu einer einheitlichen Zeichentheorie. Ch. S. Peirce' Einbettung der Semiotik in die Pragmatik. Tübingen: Stauffenburg, 1984.

Selz, Otto. Über die Gesetze des geordneten Denkverlaufs. Stuttgart: W. Spemann, 1913.

Stegmüller, Wolfgang. Kripkes Deutung der Spätphilosophie Wittgensteins. Suttgart: Kroener Alfred GmbH, 1986.

Wittgenstein, Ludwig. Dociekania filozoficzne. Tłum. Bogusław Wolniewicz. Warszawa: Wydawnictwo Naukowe PWN, 2000.

\section{Summary}

Life forms in Schema Games - and the Reverse

The article outlines the concept methodological schematic interpretationism, adhered to by its author; this is connected with Wittgensteinian philosophy of language games and life forms: schema games extend and establish the notion of language play; they can also - by means of life forms and lifeworlds - provide better grounds for effective interpretations.

Keywords: Wittgenstein, language games, life forms, lifeworld, schema games

\section{Zusammenfassung}

\section{Lebensformen in Schemaspielen - und umgekehrt}

Der methodologische Schemainterpretationskonzept des Verfassers wird skizziert und mit Wittgensteins Philosophie der Sprachspiele und Lebensformen in Verbindung gebracht: Schemaspiele erweitern und fundieren das Sprachspielkonzept und können auch die Deutungen mittels Lebensformen und Lebenswelten tiefer begründen bzw. perspektivisch fruchtbar beleuchten.

Schlüsselworte: Wittgenstein, Sprachspiele, Lebensformen, Lebenswelt, Schemaspiele 
Pobrane z czasopisma http://kulturaiwartosci.journals.umes.pl

Data: 26/04/2023 14:21:36

Hans Lenk, Formy życia w grach schematami - i na odwrót

Information about Author:

HANS LENK, professor emeritus, Karlsruhe Institute of Technology, Germany; e-mail: hans.lenk@kit.edu

(cc) EY-NC-ND 